Prepared in cooperation with the

Wisconsin Department of Natural Resources and the U.S. Environmental Protection Agency-Great Lakes National Program Office

\title{
Benthos and Plankton Community Data for Selected Rivers and Harbors Along the Western Lake Michigan Shoreline, 2014
}

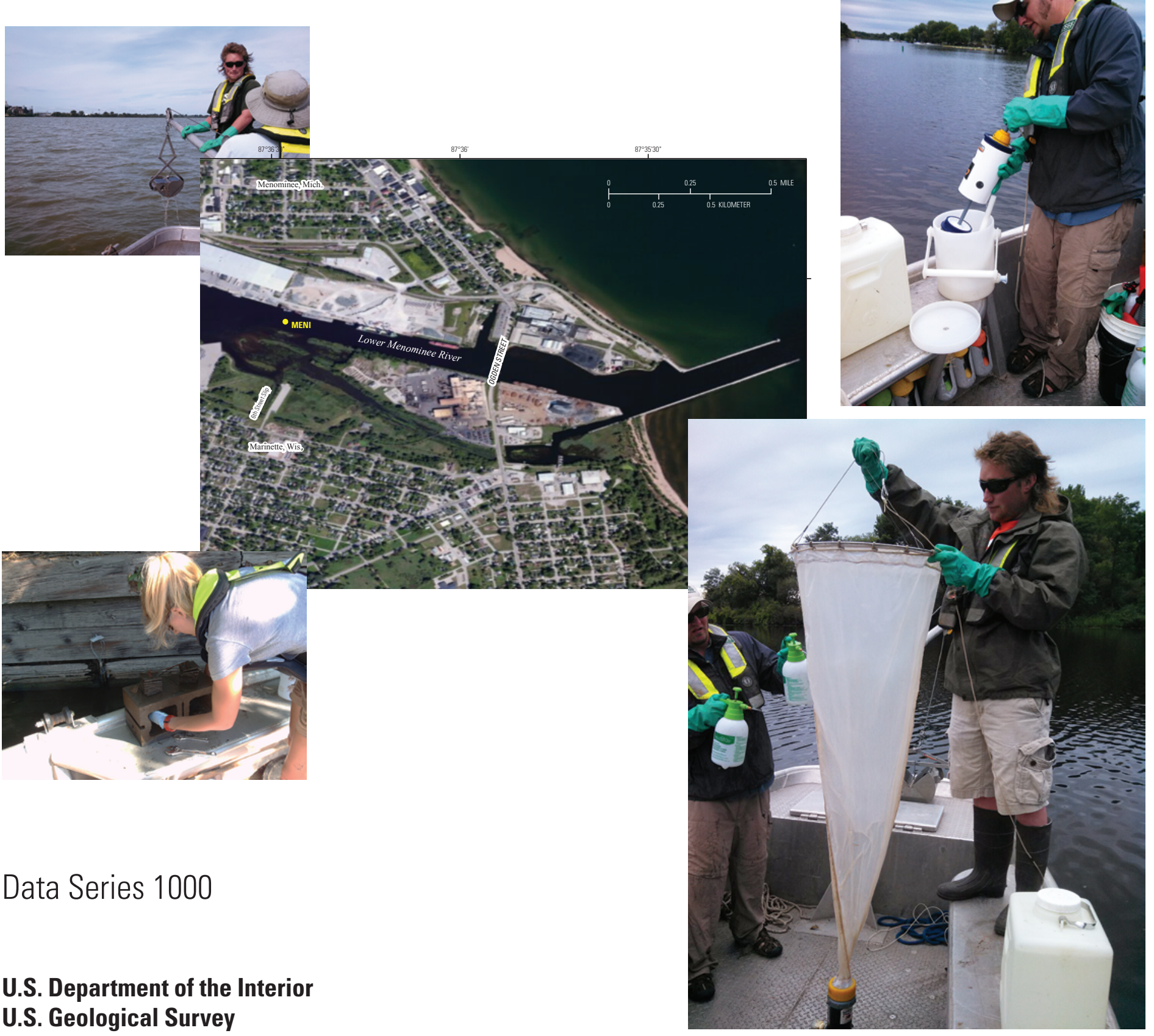


Cover. Collage of figures from within the report. 


\section{Benthos and Plankton Community Data for Selected Rivers and Harbors Along the Western Lake Michigan Shoreline, 2014}

By Barbara C. Scudder Eikenberry, Daniel J. Burns, Hayley A. Templar, Amanda H. Bell, and Kassidy T. Mapel

Prepared in cooperation with the

Wisconsin Department of Natural Resources and the

U.S. Environmental Protection Agency-Great Lakes National Program Office

Data Series 1000 


\title{
U.S. Department of the Interior SALLY JEWELL, Secretary
}

\section{U.S. Geological Survey Suzette M. Kimball, Director}

\author{
U.S. Geological Survey, Reston, Virginia: 2016
}

For more information on the USGS - the Federal source for science about the Earth, its natural and living resources, natural hazards, and the environment-visit http://www.usgs.gov or call 1-888-ASK-USGS.

For an overview of USGS information products, including maps, imagery, and publications, visit http://store.usgs.gov.

Any use of trade, firm, or product names is for descriptive purposes only and does not imply endorsement by the U.S. Government.

Although this information product, for the most part, is in the public domain, it also may contain copyrighted materials as noted in the text. Permission to reproduce copyrighted items must be secured from the copyright owner.

Suggested citation:

Scudder Eikenberry, B.C., Burns, D.J., Templar, H.A., Bell, A.H., and Mapel, K.T., 2016, Benthos and plankton community data for selected rivers and harbors along the western Lake Michigan shoreline, 2014: U.S. Geological Survey Data Series 1000, 29 p. plus 8 appendixes, http://dx.doi.org/10.3133/ds1000.

ISSN 2327-638X (online) 


\section{Acknowledgments}

This study was done in cooperation with the Wisconsin Department of Natural Resources (WDNR), with Great Lakes Restoration Initiative funding from the Great Lakes National Program Office of the U.S. Environmental Protection Agency. The authors wish to thank Cheryl Bougie, Donalea Dinsmore, Andrew Fayram, Stacy Hron, Victor Pappas, Laurel Last, Megan O'Shea, and others of the WDNR who assisted with study planning and sampling logistics; Cheryl Bougie also assisted with June sampling at the Fox River near Allouez site and July sampling at the Oconto River and Lower Green Bay sites. Dr. Kurt Schmude of the Lake Superior Research Institute at the University of Wisconsin-Superior identified and enumerated benthos; Paul Garrison and Gina LaLiberte of the WDNR and Dawn Perkins of the Wisconsin State Laboratory of Hygiene identified and enumerated plankton.

Michelle A. Lutz and James L. Kennedy of the U.S. Geological Survey (USGS) assisted with geographic information systems and creation of the figure 1 map. We would like to thank USGS reviewers Jana S. Stewart, Matthew B. Hicks, and Jonas Casey-Williams for their comments on an earlier version of the manuscript. Rosemary Stenback and Mark Bonito assisted with finalization of the figure 1 map, and Laura Nelson (USGS) assisted with finalization of maps in figures 2-15. Ann Marie Squillacci completed the publication layout. 



\section{Contents}

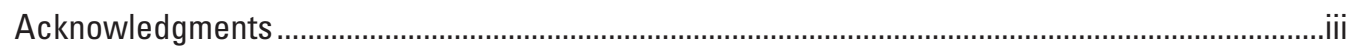

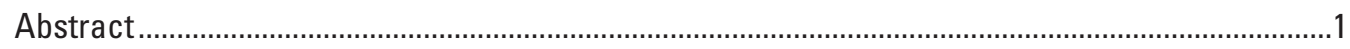

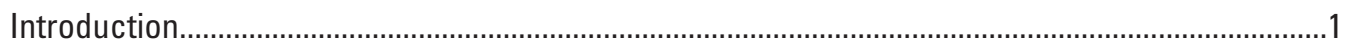

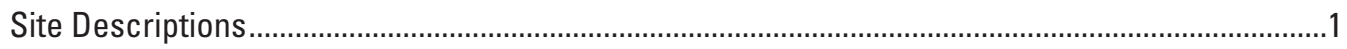

Lower Menominee River Area of Concern ...............................................................................

Lower Green Bay and Fox River Area of Concern ...................................................................

Sheboygan River Area of Concern ..................................................................................

Milwaukee Estuary Area of Concern ...................................................................................

Escanaba River Non-Area of Concern Comparison Site .....................................................13

Oconto River Non-Area of Concern Comparison Site ...........................................................13

Ahnapee River Non-Area of Concern Comparison Site ........................................................13

Kewaunee River Non-Area of Concern Comparison Site .........................................................13

Manitowoc River Non-Area of Concern Comparison Site........................................................13

Root River Non-Area of Concern Comparison Site .............................................................13

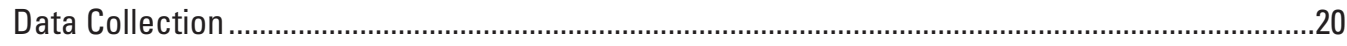

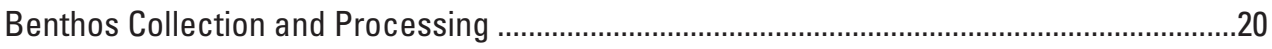

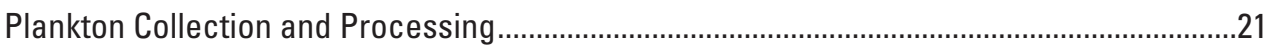

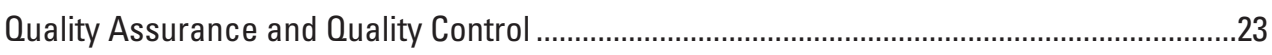

Summary

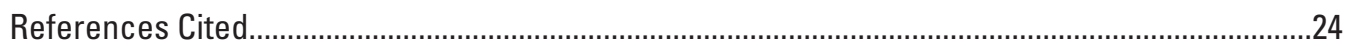

Appendixes 1-8

\section{Figures}

1. Map showing 10 sites where samples were collected for benthos and plankton communities in 2014 along Wisconsin's Lake Michigan shoreline, and land cover

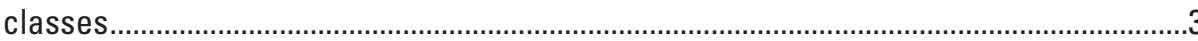

2. Map showing the U.S. Geological Survey sampling location for benthos and plankton communities in the Lower Menominee River Area of Concern, between Menominee, Michigan, and Marinette, Wisconsin

3. Map showing U.S. Geological Survey sampling locations for benthos and plankton communities in the Lower Green Bay and Fox River, Wisconsin, Area of Concern..........6

4. Map showing the U.S. Geological Survey sampling location for benthos and plankton communities in the Fox River near Allouez, Wisconsin, within the Lower Green Bay and Fox River, Wisconsin, Area of Concern

5. Map showing U.S. Geological Survey sampling location for benthos and plankton communities in the Sheboygan River, Wisconsin, Area of Concern.

6. Map showing U.S. Geological Survey sampling locations in the Milwaukee River, Menomonee River, and Milwaukee Harbor for benthos and plankton communities in the Milwaukee Estuary, Wisconsin, Area of Concern.

7. Map showing the U.S. Geological Survey sampling location for benthos and plankton communities in the Milwaukee River within the Milwaukee Estuary, Wisconsin, Area of Concern 
8. Map showing the U.S. Geological Survey sampling location for benthos and plankton communities in the Menomonee River within the Milwaukee Estuary,

Wisconsin, Area of Concern

9. Map showing the U.S. Geological Survey sampling location for benthos and plankton communities in the Milwaukee Harbor within the Milwaukee Estuary, Wisconsin, Area of Concern.

10. Map showing U.S. Geological Survey sampling locations for benthos and plankton communities in the Escanaba River, Michigan.

11. Map showing U.S. Geological Survey sampling locations for benthos and plankton communities in the Oconto River, Wisconsin

12. Map showing U.S. Geological Survey sampling locations for benthos and plankton communities in the Ahnapee River, Wisconsin .

13. Map showing U.S. Geological Survey sampling locations for benthos and plankton communities in the Kewaunee River, Wisconsin .

14. Map showing U.S. Geological Survey sampling locations for benthos and plankton communities in the Manitowoc River, Wisconsin

15. Map showing U.S. Geological Survey sampling locations for benthos and plankton communities in the Root River, Wisconsin...

16. Photograph showing a Ponar dredge being retrieved with a sediment grab for a benthos community sample.

17. Photograph showing Hester-Dendy artificial substrate samplers retrieved for benthos community assessment.

18. Photograph showing a plankton net being washed to collect a zooplankton community sample.....

19. Photograph showing a Kemmerer vertical water sampler, after retrieval from depth, being emptied into a sample splitter to collect samples for phytoplankton community, chlorophyll $a$, and suspended solids.

\section{Tables}

1. U.S. Geological Survey sampling locations at Wisconsin's Lake Michigan Areas of Concern (AOCs) and non-AOC comparison sites in Wisconsin and Michigan, including station identification number, latitude, longitude, drainage area, and discharge

2. Quality assurance and quality control $(\mathrm{QA}-\mathrm{QC})$ results for replicate samples of benthos and plankton collected in 2014 at the Sheboygan and Manitowoc Rivers, Wisconsin, showing similarity for relative abundance of taxa collected within each season 


\section{Conversion Factors}

U.S. customary units to International System of Units

\begin{tabular}{|c|c|c|}
\hline Multiply & By & To obtain \\
\hline \multicolumn{3}{|c|}{ Length } \\
\hline centimeter $(\mathrm{cm})$ & 0.3937 & inch (in.) \\
\hline millimeter (mm) & 0.03937 & inch (in.) \\
\hline meter $(\mathrm{m})$ & 3.281 & foot $(\mathrm{ft})$ \\
\hline kilometer (km) & 0.6214 & mile (mi) \\
\hline meter $(\mathrm{m})$ & 1.094 & yard (yd) \\
\hline \multicolumn{3}{|c|}{ Area } \\
\hline square kilometer $\left(\mathrm{km}^{2}\right)$ & 0.3861 & square mile $\left(\mathrm{mi}^{2}\right)$ \\
\hline \multicolumn{3}{|c|}{ Volume } \\
\hline milliliter $(\mathrm{mL})$ & 0.03381 & ounce, fluid (fl. oz) \\
\hline liter $(\mathrm{L})$ & 0.2642 & gallon (gal) \\
\hline \multicolumn{3}{|c|}{ Flow rate } \\
\hline cubic meter per second $\left(\mathrm{m}^{3} / \mathrm{s}\right)$ & 35.31 & cubic foot per second $\left(\mathrm{ft}^{3} / \mathrm{s}\right)$ \\
\hline \multicolumn{3}{|c|}{ Mass } \\
\hline gram (g) & 0.03527 & ounce, avoirdupois (oz) \\
\hline
\end{tabular}

Temperature in degrees Celsius $\left({ }^{\circ} \mathrm{C}\right)$ may be converted to degrees Fahrenheit $\left({ }^{\circ} \mathrm{F}\right)$ as follows:

$$
{ }^{\circ} \mathrm{F}=\left(1.8 \times{ }^{\circ} \mathrm{C}\right)+32 .
$$

\section{Datum}

Vertical coordinate information is referenced to the North American Vertical Datum of 1988 (NAVD 88).

Horizontal coordinate information is referenced to the North American Datum of 1983 (NAD 83).

\section{Supplemental Information}

Concentrations of chemical constituents in water are given either in milligrams per liter (mg/L) or micrograms per liter $(\mu \mathrm{g} / \mathrm{L})$.

Specific conductance is given in microsiemens per centimeter at 25 degrees Celsius $(\mu \mathrm{S} / \mathrm{cm}$ at $25^{\circ} \mathrm{C}$ ). 


\section{Abbreviations}

$\begin{array}{ll}\text { AOC } & \text { Area of Concern } \\ \text { BUI } & \text { Beneficial Use Impairment } \\ \text { EPA } & \text { U.S. Environmental Protection Agency } \\ \text { GLNPO } & \text { Great Lakes National Program Office } \\ \text { HD } & \text { Hester-Dendy [artificial substrate sampler] } \\ \text { LRSI } & \text { Lake Superior Research Institute-University of Wisconsin-Superior } \\ \text { non-AOC } & \text { non-Area of Concern comparison site } \\ \text { PAH } & \text { polycyclic aromatic hydrocarbon } \\ \text { PCB } & \text { polychlorinated biphenyl } \\ \text { OA-OC } & \text { quality assurance and quality control } \\ \text { USGS } & \text { U.S. Geological Survey } \\ \text { VOC } & \text { volatile organic compound } \\ \text { WDNR } & \text { Wisconsin Department of Natural Resources } \\ \text { WSLH } & \text { Wisconsin State Laboratory of Hygiene }\end{array}$




\title{
Benthos and Plankton Community Data for Selected Rivers and Harbors Along the Western Lake Michigan Shoreline, 2014
}

\author{
By Barbara C. Scudder Eikenberry, Daniel J. Burns, Hayley A. Templar, Amanda H. Bell, and Kassidy T. Mapel
}

\section{Abstract}

Benthos (benthic invertebrates) and plankton (zooplankton and phytoplankton) communities were sampled in 2014 at 10 Wisconsin rivers and harbors, including 4 sites in Great Lakes Areas of Concern and 6 less degraded comparison sites with similar physical and chemical characteristics, including climate, latitude, geology, and land use. Previous U.S. Geological Survey sampling was completed in 2012, but because of ongoing sediment remediation at three of the Areas of Concern (AOCs) and unusually hot and dry conditions in many areas during 2012, additional sampling was added in 2014. Comparable sampling methods were used in 2012 and 2014. Benthos were collected by using Hester-Dendy artificial substrate samplers and composite Ponar grab samples of bottom sediment; zooplankton were collected by using tows from depth to the surface with a 63-micrometer mesh plankton net; phytoplankton were collected by using whole water samples composited from set depth intervals. This report describes the study areas and field sampling methods for 2014, and it presents data on taxonomic identification and abundance of benthos and plankton that can serve as a basis for evaluation of related Beneficial Use Impairments (BUIs) at the AOCs. Physical and chemical data were sampled concurrently (specific conductance, temperature, $\mathrm{pH}$, dissolved oxygen, chlorophyll $a$, total and volatile suspended solids in water samples; particle size and volatile-on-ignition of sediment in benthic grab samples). The results of field quality assurance-quality control are also presented.

\section{Introduction}

In 2012 and 2014, the U.S. Geological Survey (USGS), in cooperation with the Wisconsin Department of Natural Resources (WDNR) and the U.S. Environmental Protection Agency (EPA), collected benthos (bottom-dwelling invertebrates) and plankton (zooplankton and phytoplankton) at 10 sites in rivers and harbors along Wisconsin's Lake Michigan shoreline. Four sites were in designated Areas of Concern
(AOCs), and six sites were less degraded comparison sites with similar physical and chemical characteristics but were not designated AOCs (referred to hereafter as non-AOCs). Each AOC is designated or "listed" because it has at least 1 of 14 defined Beneficial Use Impairments (BUIs). A BUI is an adverse change or condition of a Great Lakes area that causes impairment in the area's chemical, physical, or biological integrity, such as degradation of benthos or plankton populations, that limits the area's ability to support aquatic life.

The overall goal of the study was to inform the decisionmaking process with regard to removal of the BUI for degradation of benthos and the BUI for degradation of plankton populations. The purpose of this report is to describe the study areas and field sampling methods for 2014 and to present data on taxonomic identification and abundance of benthos and plankton that can serve as a basis for evaluation of related BUIs at the AOCs. Benthos were collected by using a grab sampler and artificial substrate samplers; plankton were collected with a tow net for zooplankton and a vertical water sampler for phytoplankton. Physical and chemical data were sampled concurrently (specific conductance, temperature, $\mathrm{pH}$, dissolved oxygen, chlorophyll $a$, total and volatile suspended solids in water samples; particle size and volatile-on-ignition of sediment in benthic grab samples), and the results of field quality assurance and quality control (QA-QC) are also presented. Methods and data for 2012 were published previously (Scudder Eikenberry and others, 2014).

\section{Site Descriptions}

In the late 1980s, 43 sites around the Great Lakes were designated as AOCs by the United States and Canada because of pollution (International Joint Commission, United States and Canada, 1987). Sites in 4 of these 43 AOCs and 6 nonAOC comparison sites were selected for this study (table 1, fig. 1). The $4 \mathrm{AOC}$ sites are the Lower Menominee River, Lower Green Bay and Fox River, Sheboygan River, and Milwaukee Estuary; the 6 non-AOC sites are the Escanaba River, Oconto River, Ahnapee River, Kewaunee River, 


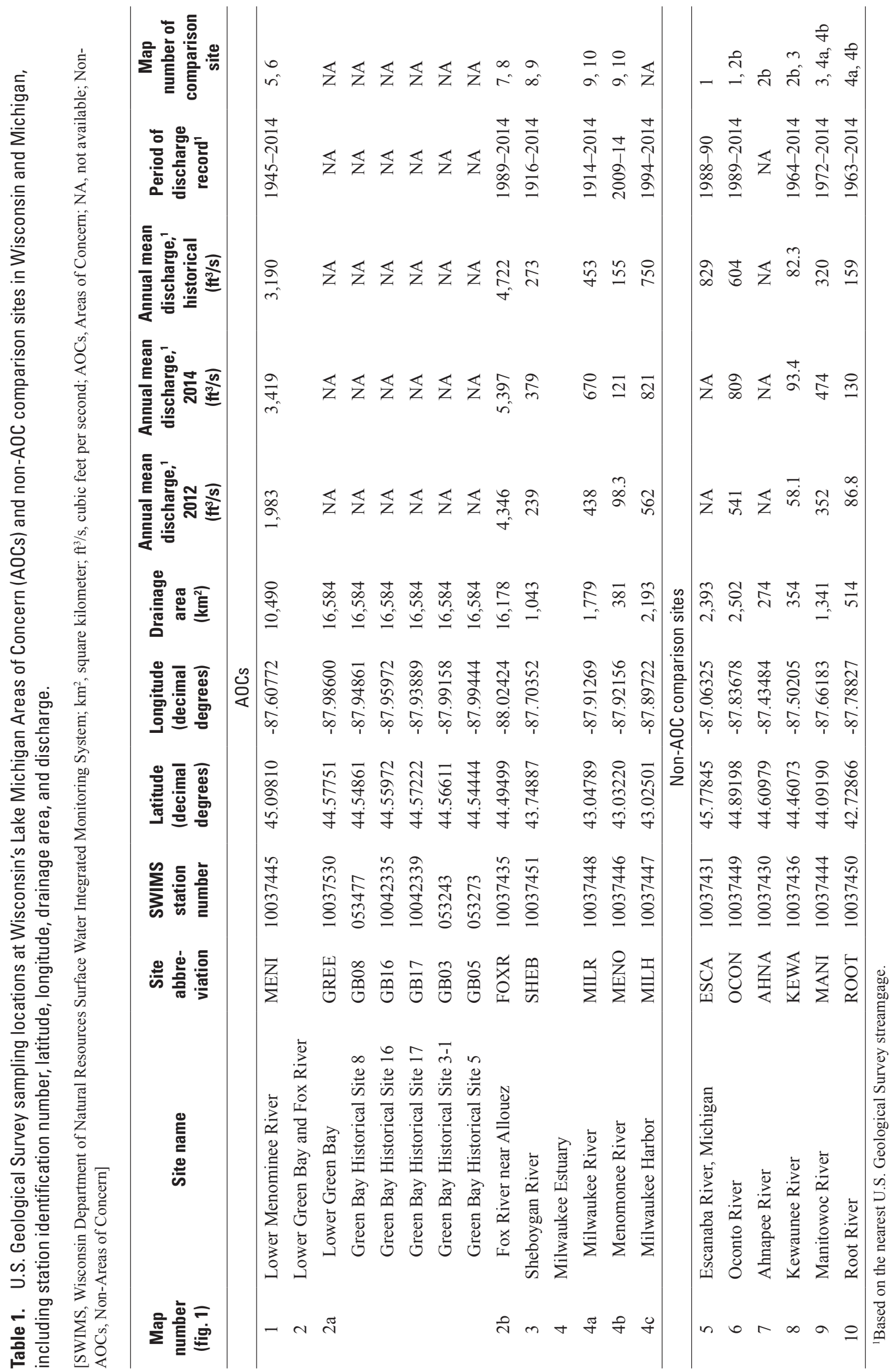




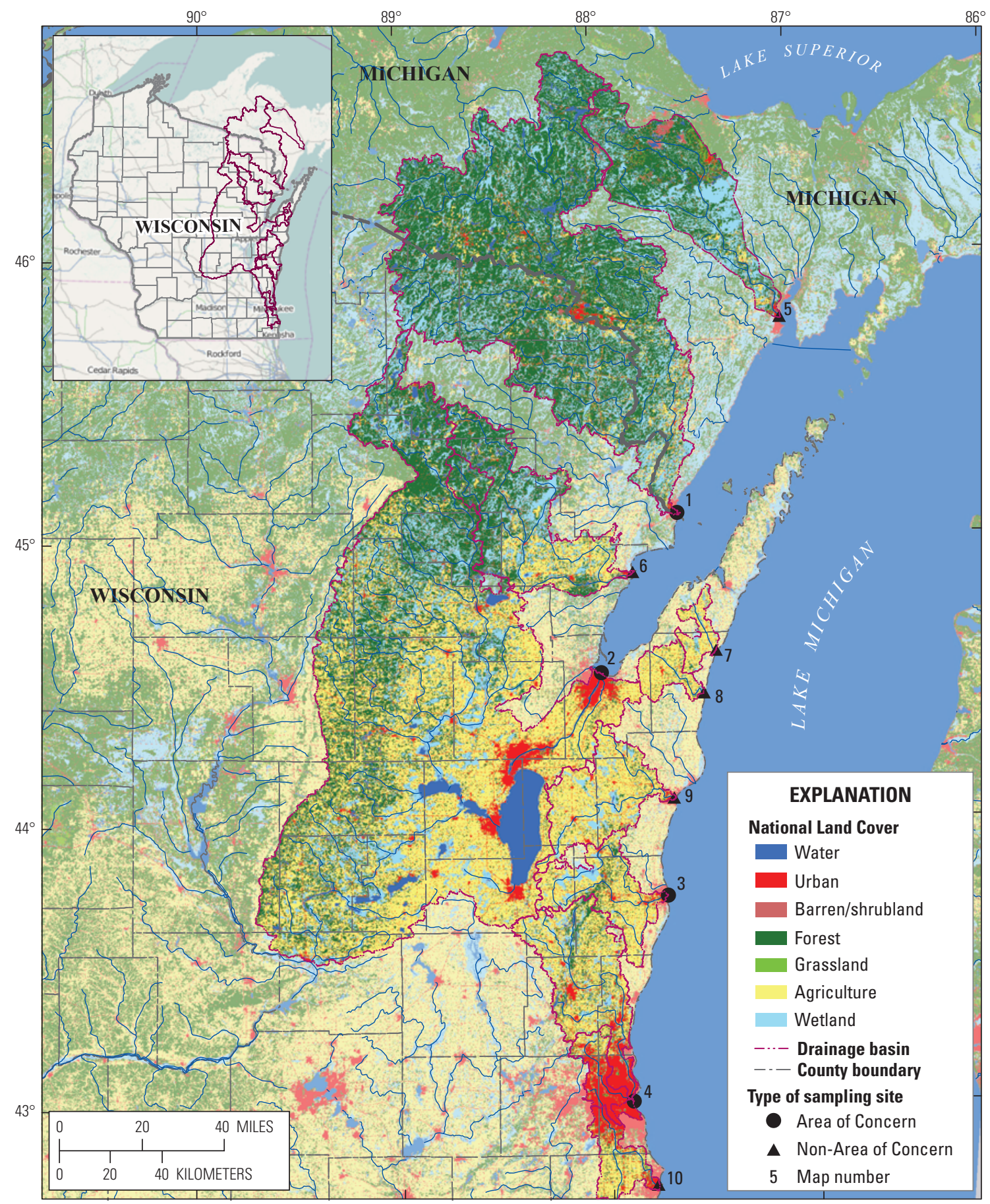

Base map is the intellectual property of Esri and is used herein under license. (2013 Esri, DeLorme, NAVTE0 All rights reserved

Figure 1. 10 sites where samples were collected for benthos and plankton communities in 2014 along Wisconsin's Lake Michigan shoreline, and land cover classes. See table 1 for site names and sampling location information. 
Manitowoc River, and Root River. The term "site" refers to a geographic area being sampled (for example, the Lower Green Bay and Fox River AOC). The term "location" refers to the specific area of sampling within a site. Detailed site information including land use-land cover is provided in Scudder Eikenberry and others (2014).

\section{Lower Menominee River Area of Concern}

The Lower Menominee River AOC along the WisconsinMichigan border is the northernmost AOC in the study (figs. 1 and 2, table 1), and it has a drainage area of 10,490 square kilometers $\left(\mathrm{km}^{2}\right)$. It was designated an AOC because of sediment contamination with arsenic, polychlorinated biphenyls (PCBs), polycyclic aromatic hydrocarbons (PAHs, or coal tars), paint sludge, and heavy metals including cadmium, chromium, copper, lead, mercury, nickel, and zinc (Wisconsin Department of Natural Resources and Michigan Department of Environmental Quality, 2011). This AOC has a BUI for benthos but not for plankton. Contaminated sediment removal began in 2009 and continued through 2014 (U.S. Environmental Protection Agency, 2013b; Wisconsin Department of Natural Resources, 2015a). The sampling location (MENI) for benthos and plankton was the same as in 2012, downstream of the dredging area in the main channel and slightly upstream of the 6th Street Slip. In 2014, to avoid issues encountered with ongoing dredging operations, the artificial substrate samplers (Hester-Dendy or HD samplers) were deployed less than 0.4 kilometer $(\mathrm{km})$ downstream of the dredge site and the 2012 HD sampler site, off the right bank of the main channel. The Escanaba and Oconto Rivers were used as comparable river systems for the Lower Menominee River because of similar climate (cooler temperatures and greater snowfall than the more southern AOCs) and geology.

\section{Lower Green Bay and Fox River Area of Concern}

The Lower Green Bay and Fox River AOC (fig. 3), with a drainage area of $16,584 \mathrm{~km}^{2}$, is the largest system in this study. It is located near the confluence of the Fox River with Green Bay. The bay is different from any other system in the Great Lakes because of its size and unique circulation patterns. The Fox River historically had discharges of contaminants, primarily PCBs that were noted as the main cause of AOC designation; nutrient enrichment is also a problem (U.S. Environmental Protection Agency, 2013a; Wisconsin Department of Natural Resources, 2014a). Extensive remediation efforts including removal of contaminated sediment are underway and will continue through at least 2017. Benthos and plankton samples were collected at two locations that this study also sampled in 2012: in Green Bay, just southeast of Dead Horse Bay (GREE) (fig. 3, table 1), and in the Fox River near Allouez, Wisconsin, downstream of State Highway 172 at the railroad bridge (FOXR) (fig. 4, table 1). In 2014, benthos grab samples were collected at five additional locations (GB03, GB05, GB08, GB16, and GB17) of historical benthos sampling in Green Bay. Despite smaller drainage areas, the Ahnapee River and Kewaunee River were chosen as sites of comparison to the Fox River on the basis of similar climate, latitude, and geology. Green Bay, however, could not be compared directly to any other non-AOC system in the Great Lakes because of its unique characteristics.

\section{Sheboygan River Area of Concern}

The Sheboygan River (fig. 5, table 1), with a drainage area of $1,043 \mathrm{~km}^{2}$, is the smallest of the AOC watersheds. The $\mathrm{AOC}$ was designated because of concerns about sediment contamination from PCBs, PAHs, volatile organic compounds (VOCs), and heavy metals (Wisconsin Department of Natural Resources, 1995, 2012). Sediment dredging for remediation was completed in June 2013 (Wisconsin Department of Natural Resources, 2013, 2014c). The USGS sampling location (SHEB) was downstream of the dredged areas and near the mouth of the river below the 8th Street Bridge. The non-AOC sites used as comparison sites for the Sheboygan River AOC are the Kewaunee and Manitowoc Rivers because of similar climate, latitude, geology, and land use. The Manitowoc River and Sheboygan River also have similar drainage areas.

\section{Milwaukee Estuary Area of Concern}

At the Milwaukee Estuary AOC, three rivers converge to form the Milwaukee Inner Harbor before flowing into Lake Michigan (fig. 6). The Milwaukee River (fig. 7, table 1) is the largest river, with a drainage area of $1,779 \mathrm{~km}^{2}$, and the sampling site (MILR) was about $0.15 \mathrm{~km}$ upstream of Knapp Street. The Menomonee River (fig. 8, table 1) has a drainage area of $381 \mathrm{~km}^{2}$, and the sampling site (MENO) was immediately downstream of the North-South Freeway. The Kinnickinnic River was not sampled because of its small size (less than $65 \mathrm{~km}^{2}$ ) and generally shallow depth, which posed problems with sampling logistics. The Milwaukee Harbor sampling site (MILH) was adjacent to the USGS streamgage at Jones Island (fig. 9, table 1). Contaminants of concern in the Milwaukee Estuary AOC are mainly PCBs, PAHs, pesticides, and heavy metals, such as cadmium, copper, and zinc (Wisconsin Department of Natural Resources, 1994, 2014b). Sediment remediation is in progress. The original AOC boundary established in the late 1980s was expanded in 2008 to include upstream reaches with known sources of contamination (U.S. Environmental Protection Agency, 2013c). The non-AOC comparison sites for the Milwaukee and Menomonee Rivers were the Manitowoc and Root Rivers because of similar climate, geology, and land use. The Milwaukee River and Manitowoc River are similar in drainage area, and the Menomonee River and Root River are similar in drainage area. 

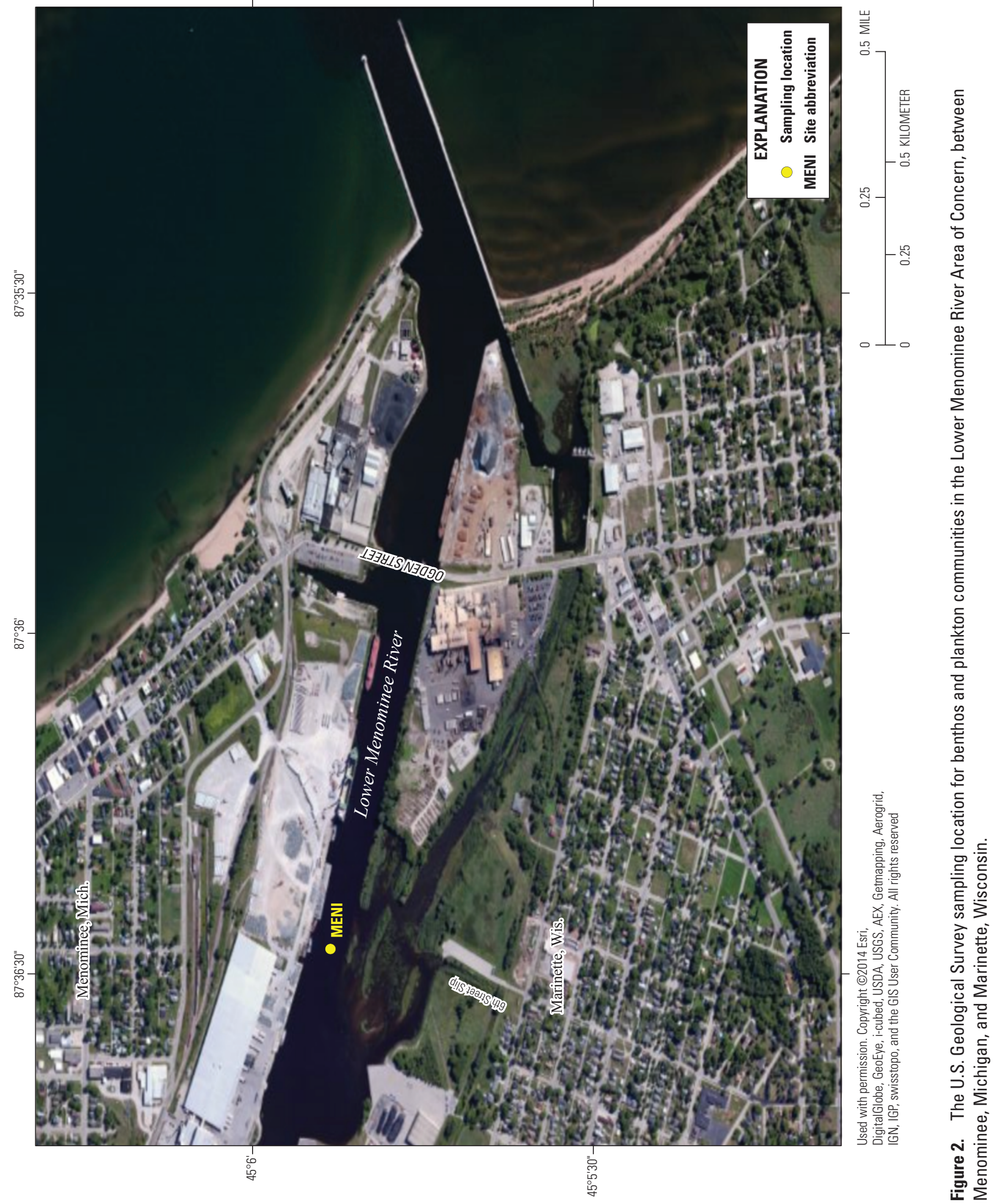


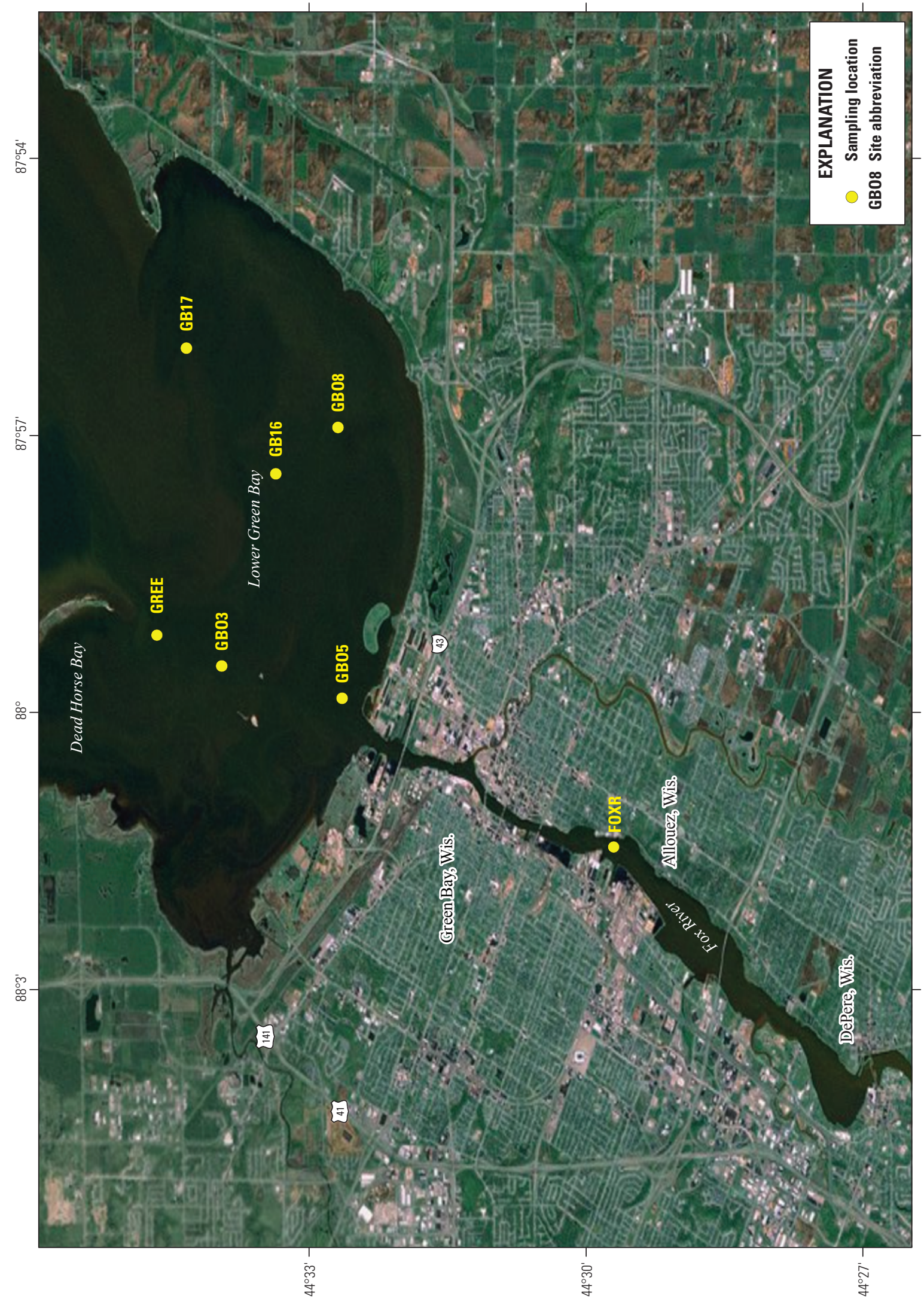




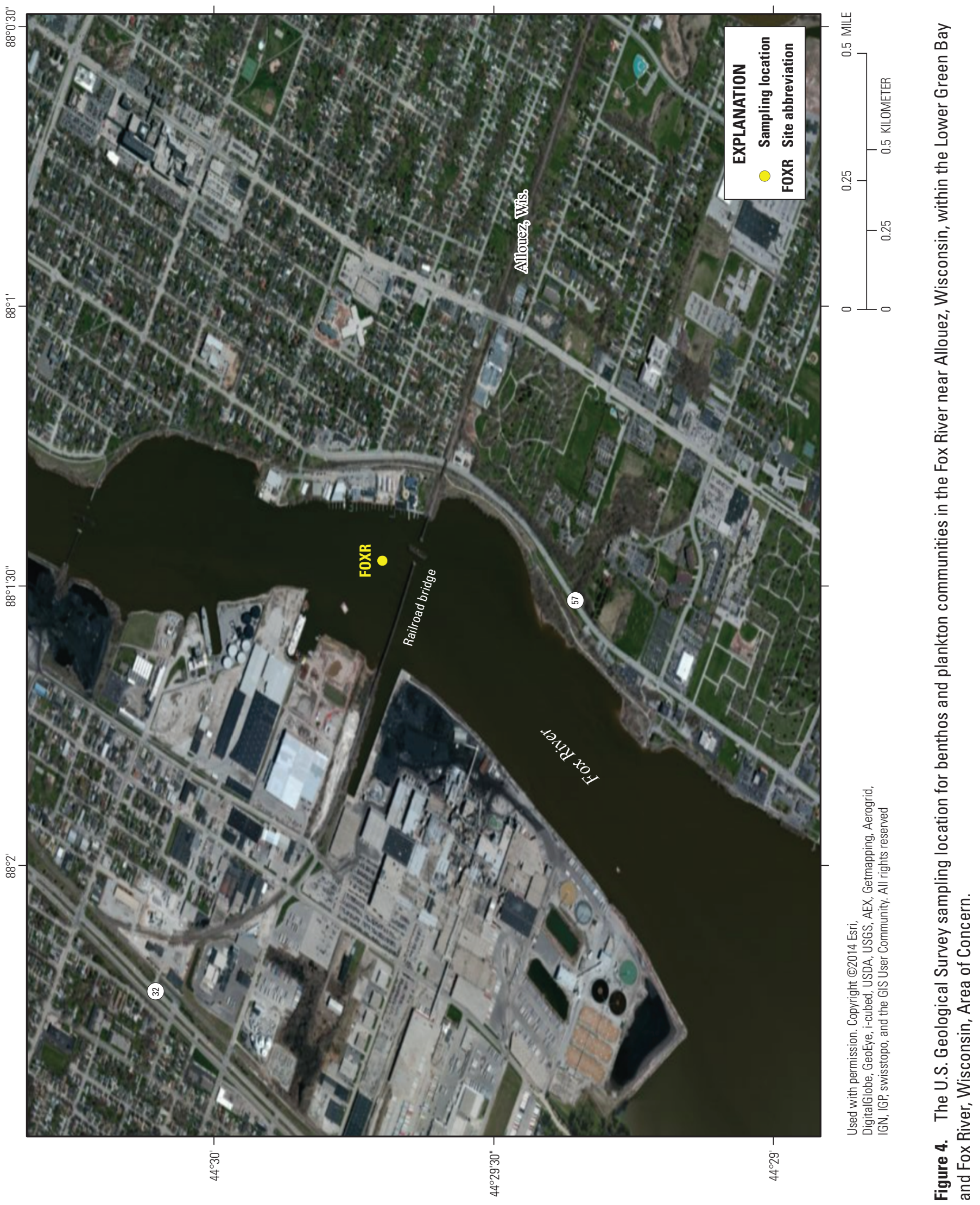




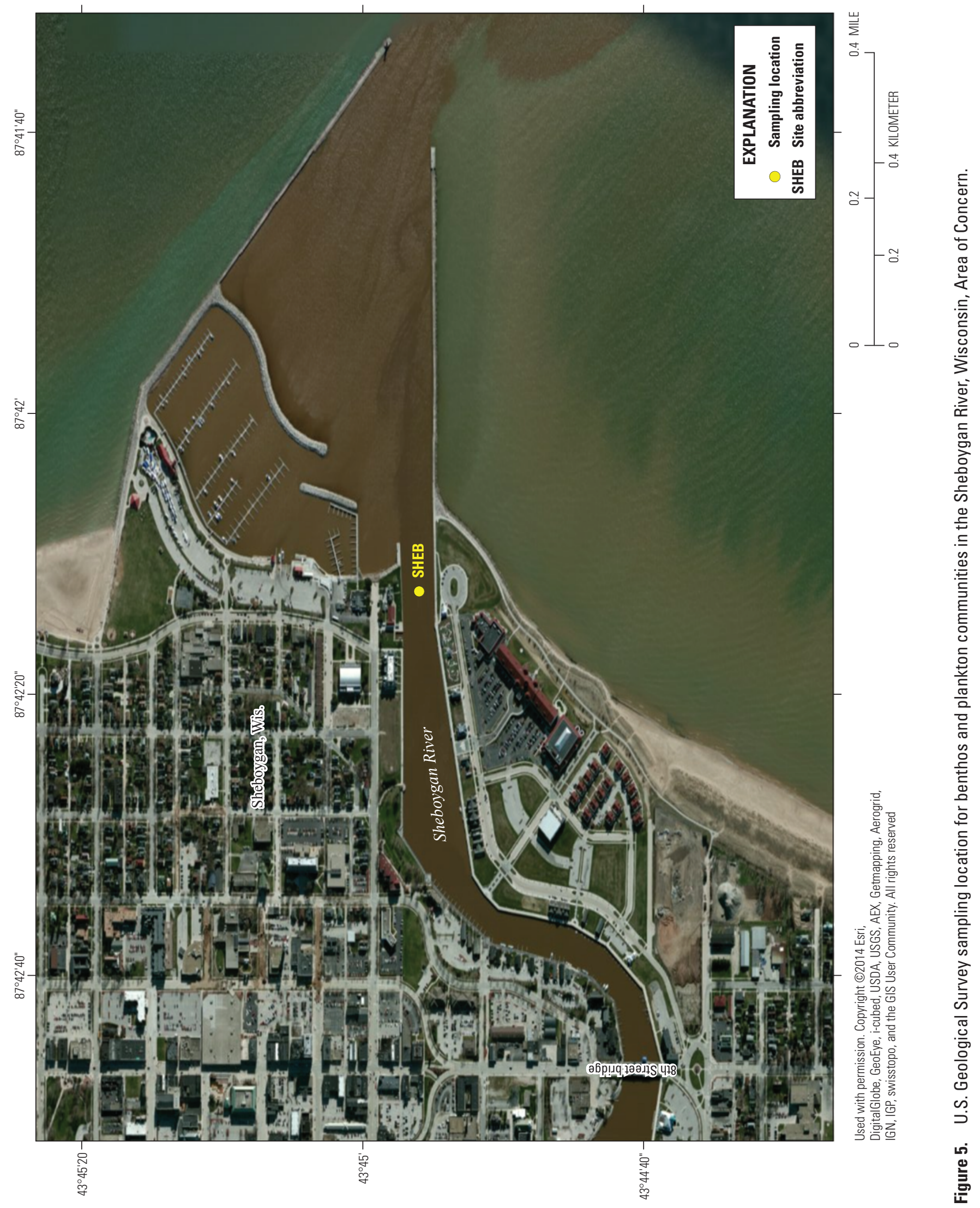




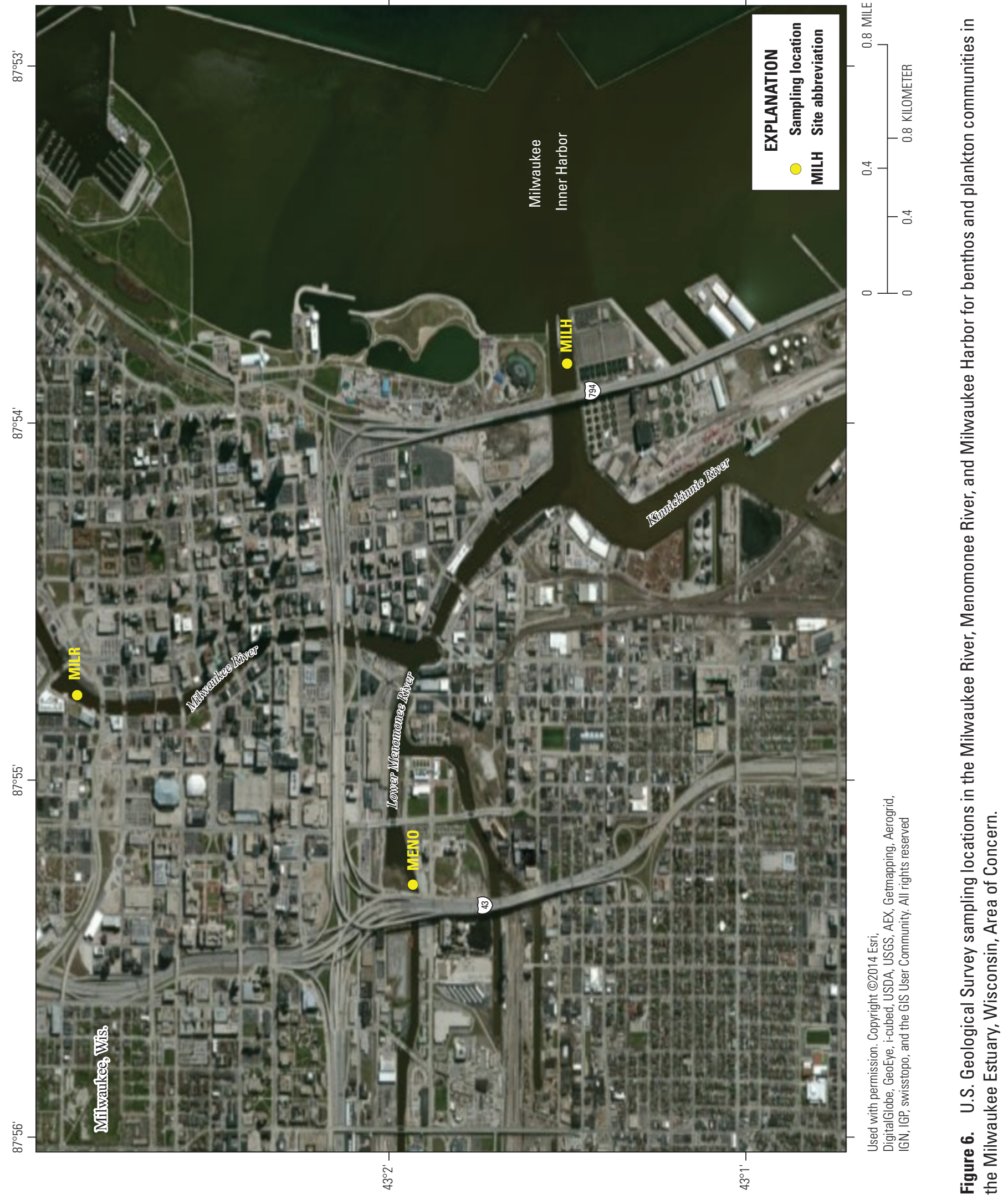




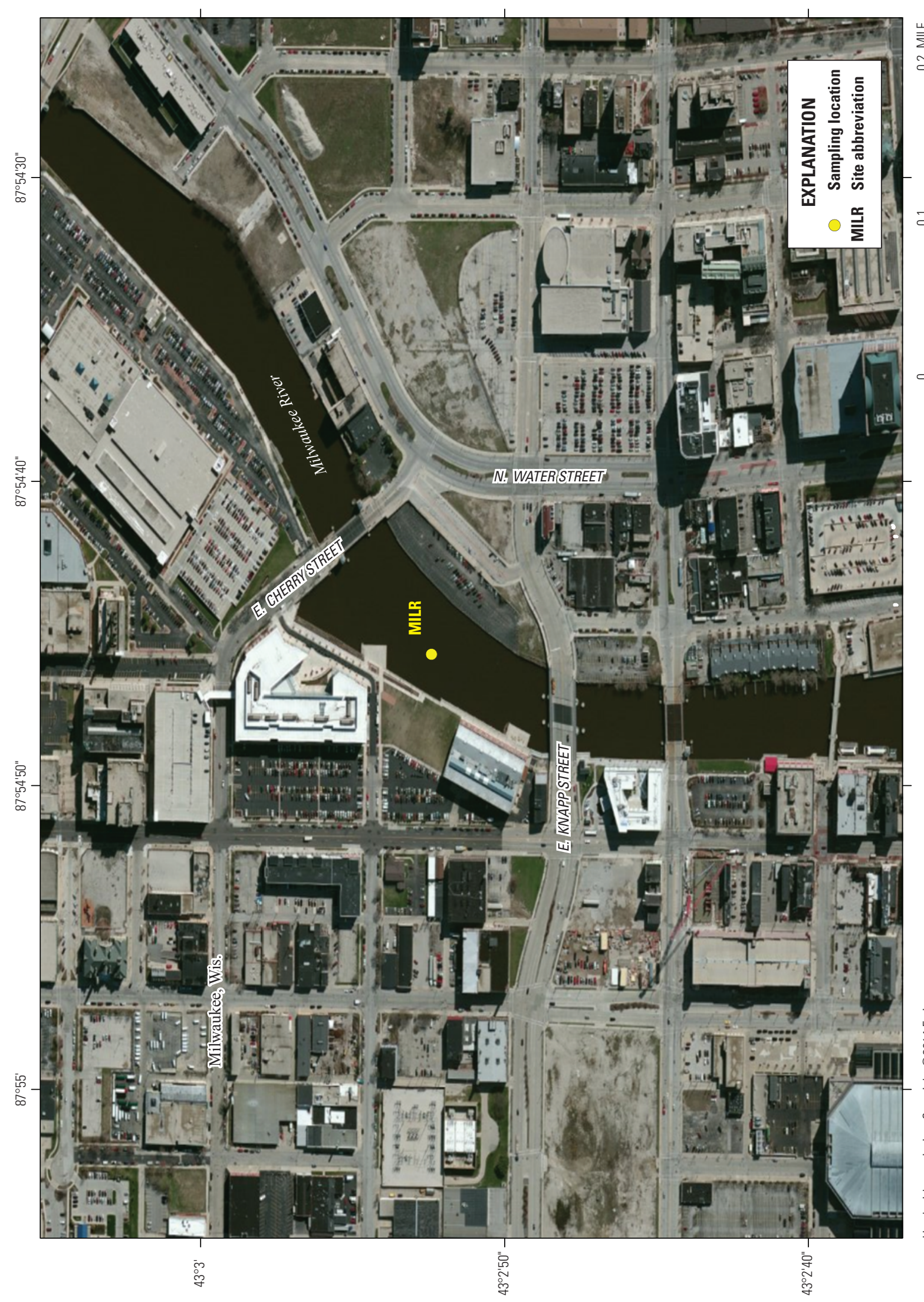

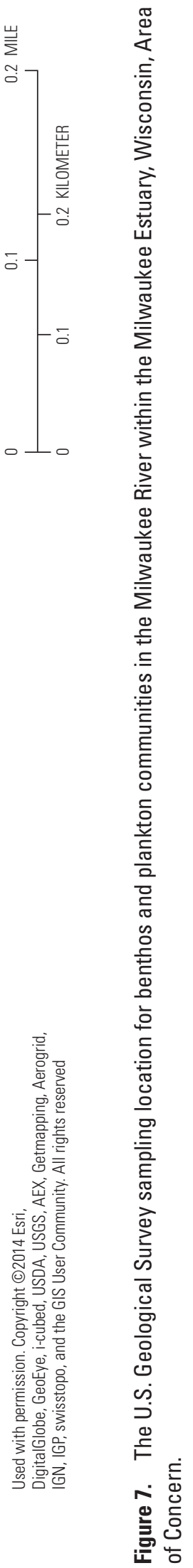



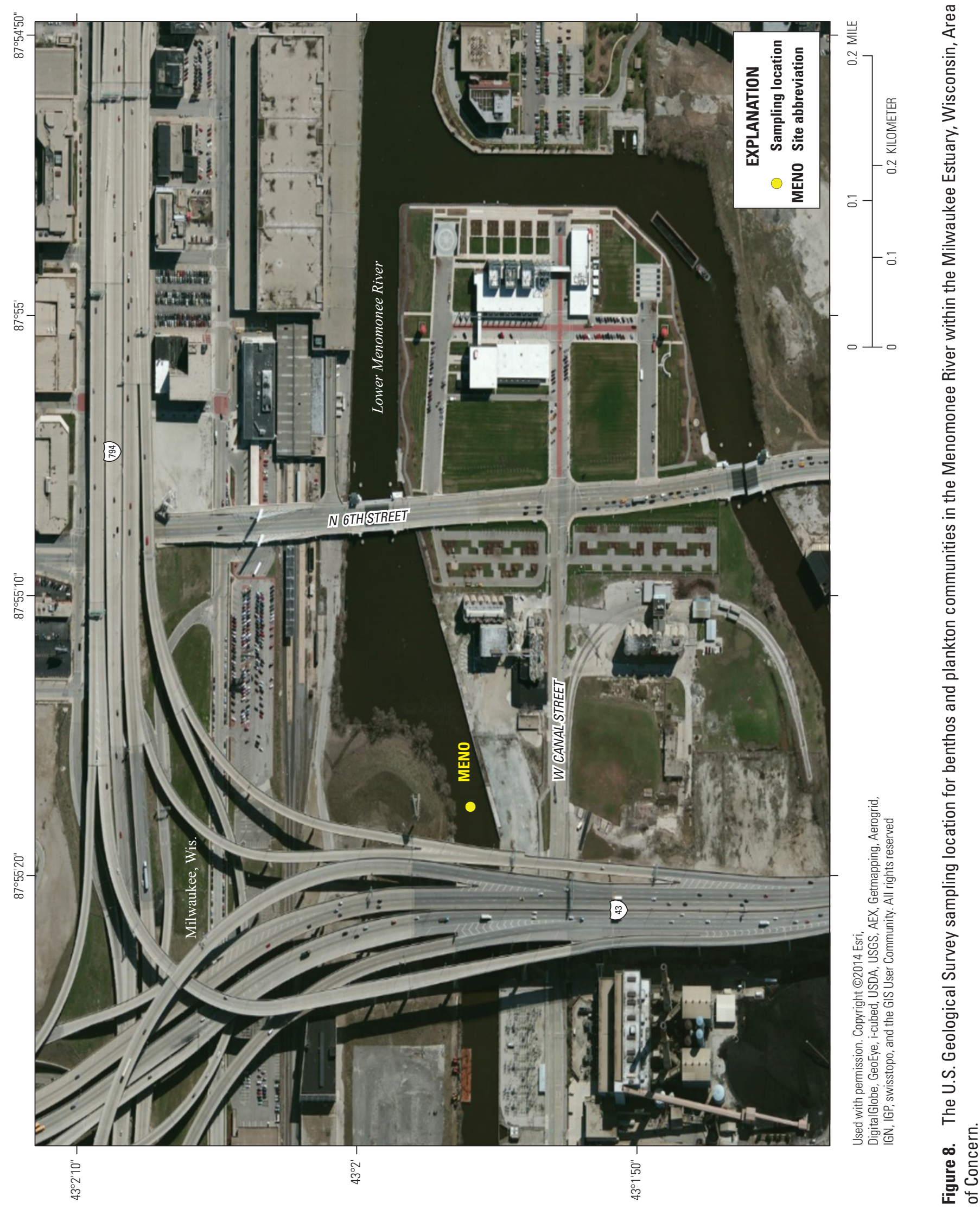

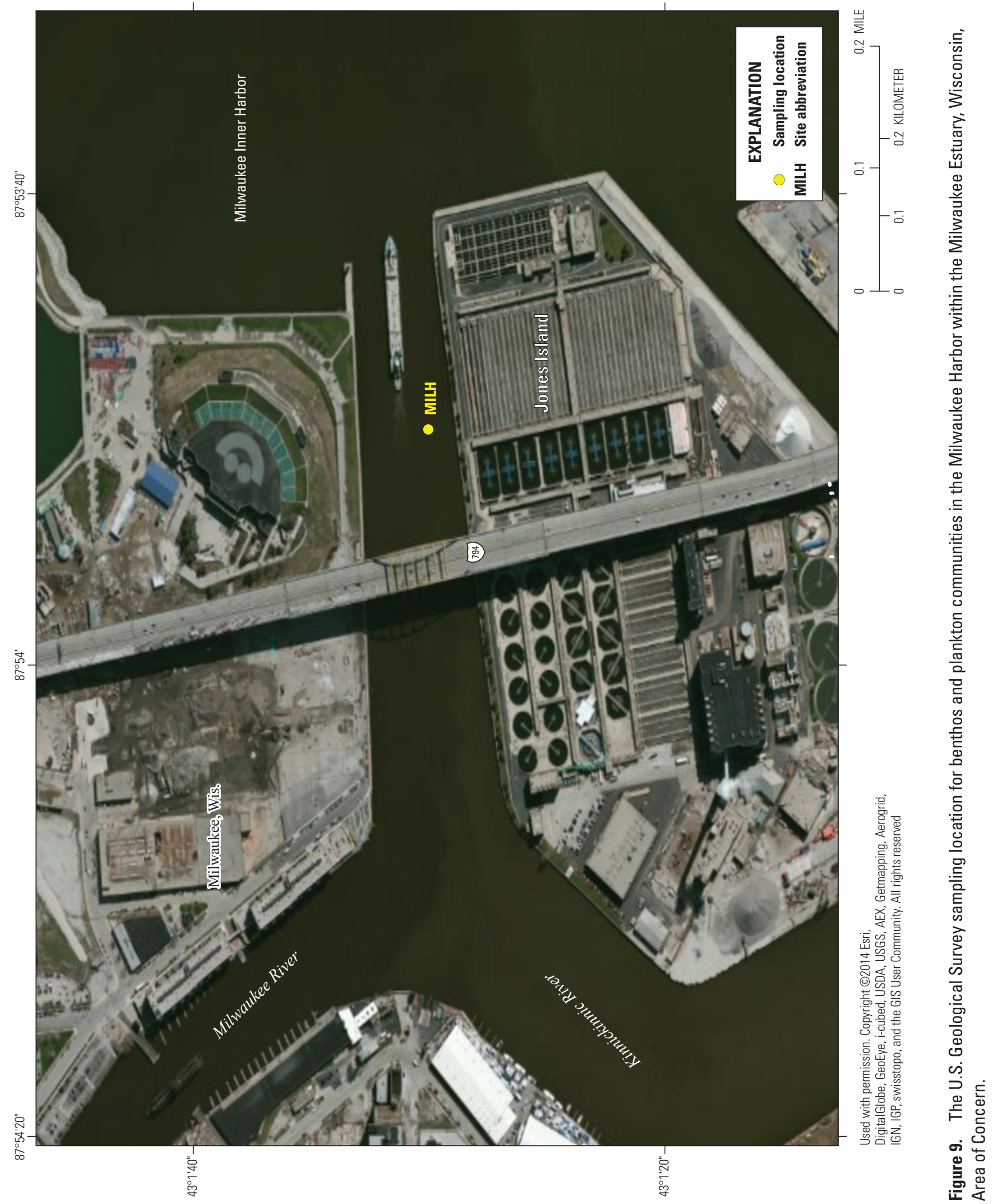


\section{Escanaba River Non-Area of Concern Comparison Site}

The Escanaba River (fig. 10, table 1) in Michigan's Upper Peninsula was selected as a non-AOC comparison site for the Lower Menominee River on the basis of similar climate and geology. In addition, both the Lower Menominee and the Escanaba Rivers are coldwater rivers with relatively high gradients and portions flowing over bedrock. Because of these similarities, the Lower Menominee and Escanaba Rivers would be expected to have similar benthos communities, despite the significantly smaller size of the Escanaba River drainage area $\left(2,393 \mathrm{~km}^{2}\right)$ than that of the Lower Menominee River $\left(10,490 \mathrm{~km}^{2}\right)$. Because of legacy contamination in the Escanaba River, there are fish consumption warnings for PCB and mercury (Michigan Department of Community Health, 2015) and some urban runoff. The sampling location (ESCA) was about $2 \mathrm{~km}$ downstream of Dam 1 near the boat launch at the mouth of the river.

\section{Oconto River Non-Area of Concern Comparison Site}

The Oconto River (fig. 11, table 1) was selected as a nonAOC comparison site for the Lower Menominee River. The Oconto has a smaller drainage area $\left(2,502 \mathrm{~km}^{2}\right)$ than the other two rivers, but it is a coldwater stream with similar climate and geology. Despite historical contamination from paper mills and water-treatment facilities, conditions improved with the halting of paper pulping operations and improvements to water-treatment facilities (Rost and others, 1989). The sampling location (OCON) was about $1.8 \mathrm{~km}$ upstream of the mouth.

\section{Ahnapee River Non-Area of Concern Comparison Site}

The Ahnapee River (fig. 12, table 1) is a small river approximately $48 \mathrm{~km}$ northeast of the mouth of the Fox River. Although it drains to Lake Michigan rather than Green Bay and has a much smaller drainage area $\left(274 \mathrm{~km}^{2}\right)$ than the Fox River $\left(16,178 \mathrm{~km}^{2}\right)$, its proximity to the Fox River along with similar climate, latitude, and geology lends to a comparison. Other than water-treatment facilities, no industries directly discharge into the river. The sampling location (AHNA) was about $0.1 \mathrm{~km}$ downstream of the 2nd Street Bridge in Algoma, Wis.

\section{Kewaunee River Non-Area of Concern Comparison Site}

The Kewaunee River (fig. 13, table 1) is a small $\left(354 \mathrm{~km}^{2}\right)$, predominantly agricultural watershed. Despite its smaller drainage area, it was chosen as a comparison site for the Fox and Sheboygan Rivers because of similar climate, latitude, geology, and land use. Sediment sampling in 1988 by the WDNR found moderate levels of petroleum products, total phosphorus, lead, and chemical oxygen demand in sediments (Wisconsin Department of Natural Resources and Lakeshore Basin Partnership Team, 2001a). Along with nonpoint source contaminants from agricultural and urban runoff in the watershed, water-treatment facilities and several industries in the watershed may contribute contaminants to the river. The sampling location (KEWA) was near the State Highway 42 Bridge.

\section{Manitowoc River Non-Area of Concern Comparison Site}

The Manitowoc River (fig. 14, table 1) is approximately $40 \mathrm{~km}$ north of the Sheboygan River. It was selected as a comparison site for the Sheboygan, Milwaukee, and Menomonee Rivers on the basis of similarities in drainagearea size, climate, latitude, geology, and land use. The land cover is predominantly agricultural and includes areas of protected wetlands and urban land cover primarily near the river mouth. Multiple water-treatment facilities and industries discharge to the river, which has had a fish consumption advisory from the mouth upstream to the first dam for more than 35 years because of PCBs (Wisconsin Department of Natural Resources, 2015b). In addition, continued monitoring takes place at an EPA Superfund site, which borders the left bank of the river about a mile upstream from its mouth, where studies and cleanups took place from 1988 through 1994 to address volatile organic compounds, PAHs, and cyanide (U.S. Environmental Protection Agency, 2015). Despite these known chemical issues, this river was selected as a non-AOC comparison site because it has a setting similar to the Sheboygan, Milwaukee, and Menomonee River AOCs and is not an AOC. The sampling location (MANI) was just upstream of the 10th Street Bridge.

\section{Root River Non-Area of Concern Comparison Site}

The Root River (fig. 15, table 1) was selected as a comparison site for the Milwaukee and Menomonee Rivers on the basis of its similar climate, latitude, geology, and land use as well as a drainage area comparable in size to that of the Menomonee River. The Root River drainage area is approximately $514 \mathrm{~km}^{2}$, and the land use is mostly urban in the headwaters near Milwaukee, agricultural in the middle drainage area, and highly urban at the mouth in Racine. There are fish consumption advisories for PCBs and heavy metals for the Root River, and several water-treatment facilities and industries discharge into it (Wisconsin Department of Natural Resources and Lakeshore Basin Partnership Team, 2001b). The sampling location (ROOT) was near the corner of Villa Street and Water Street, upstream of the State Street Bridge. 


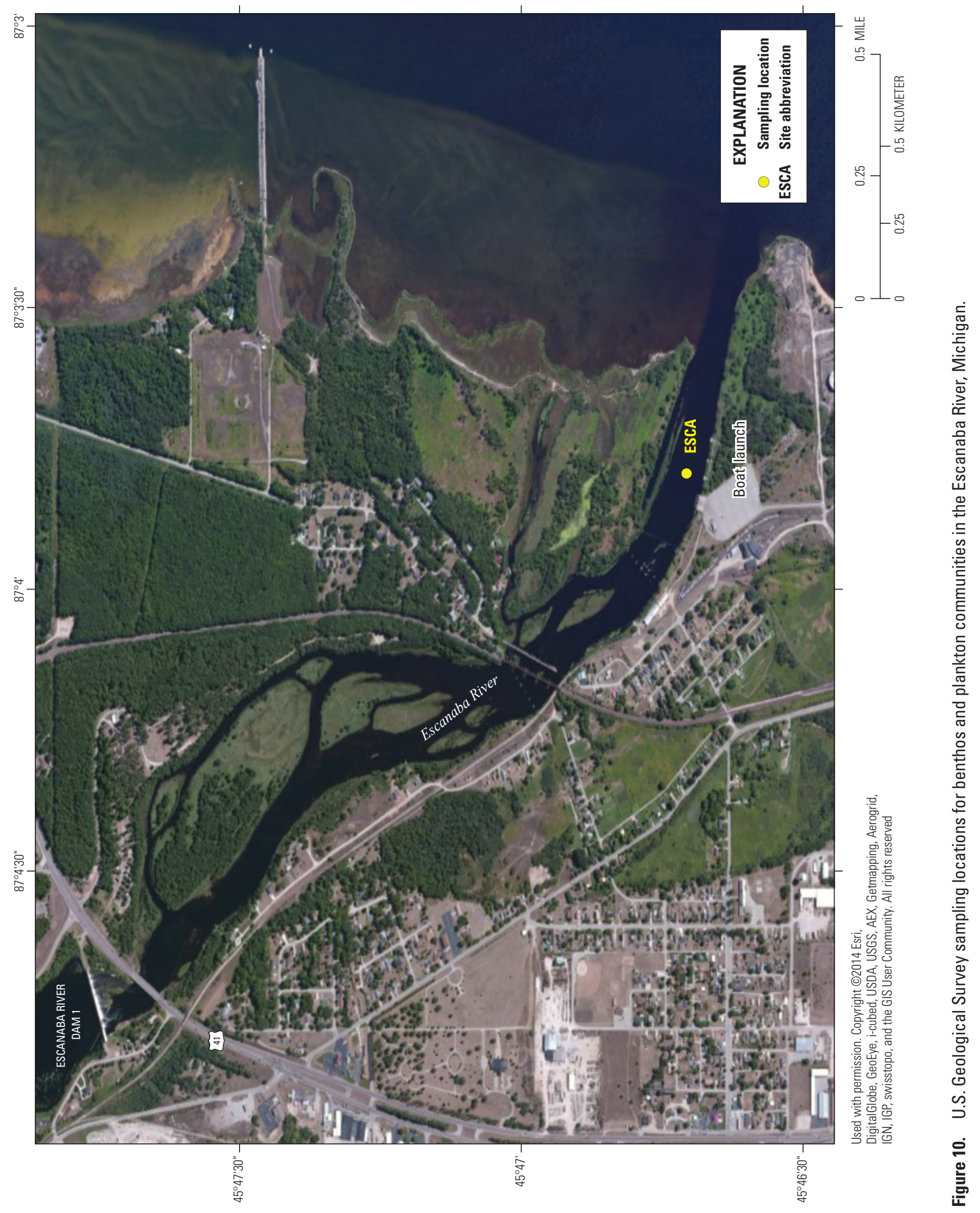




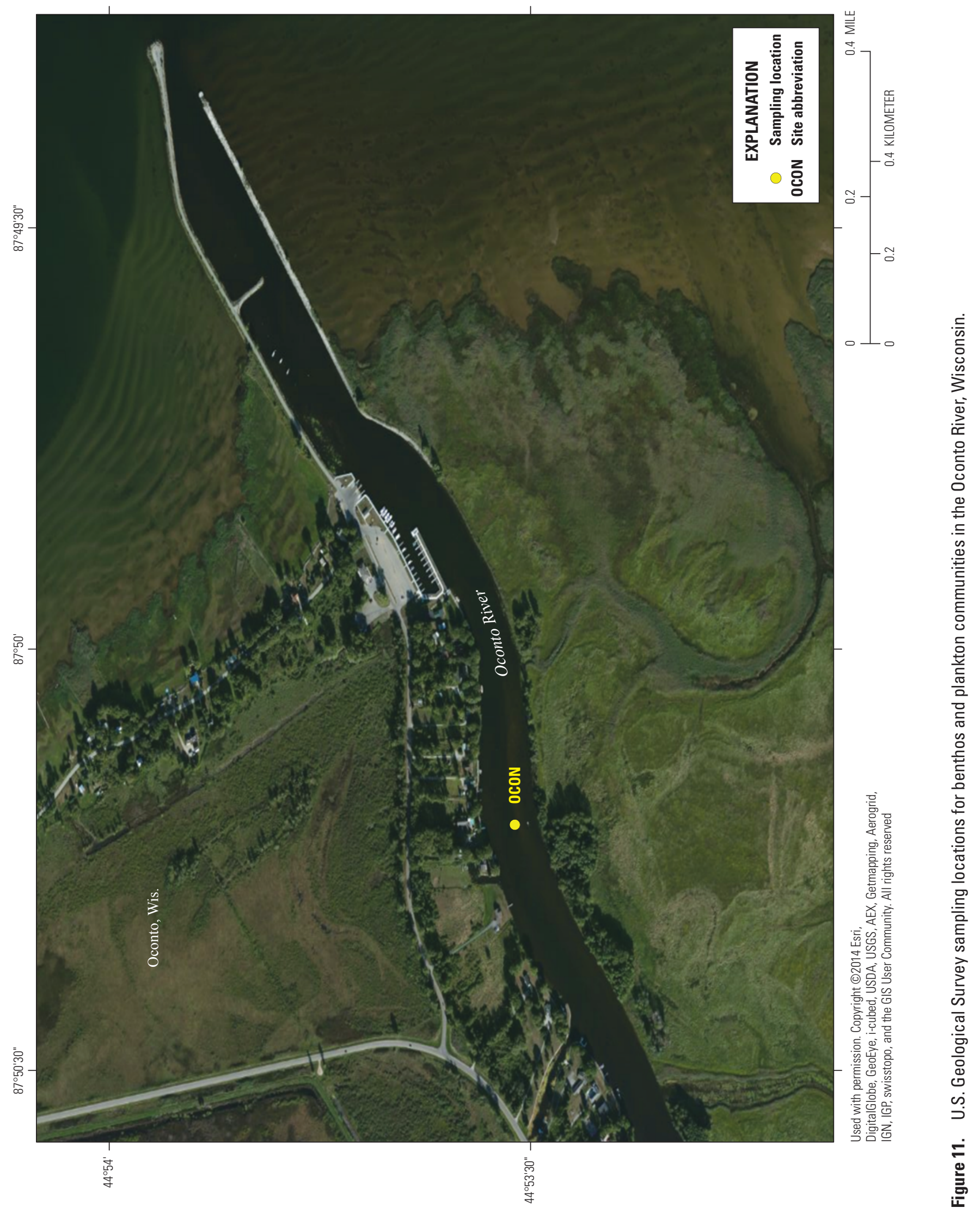




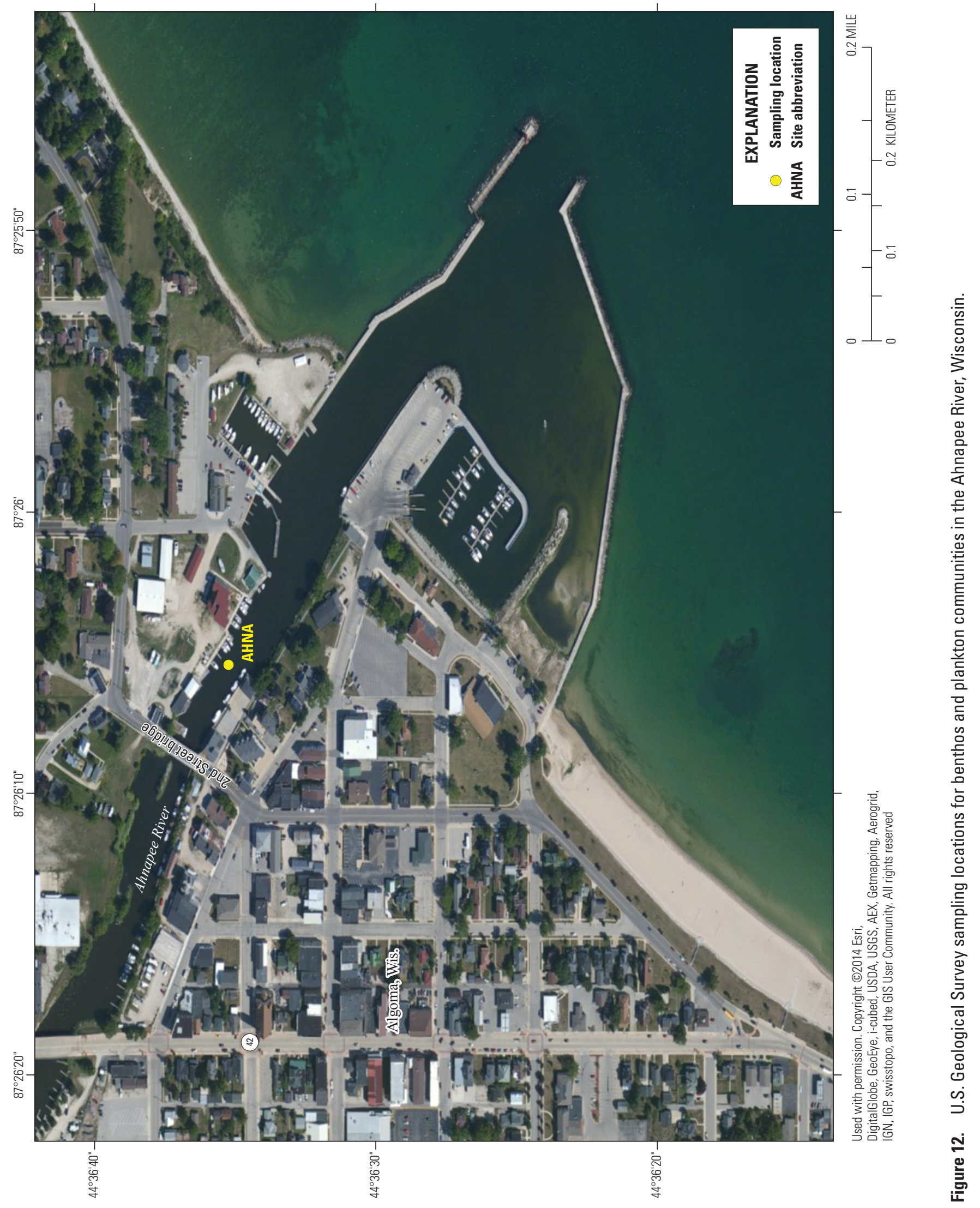




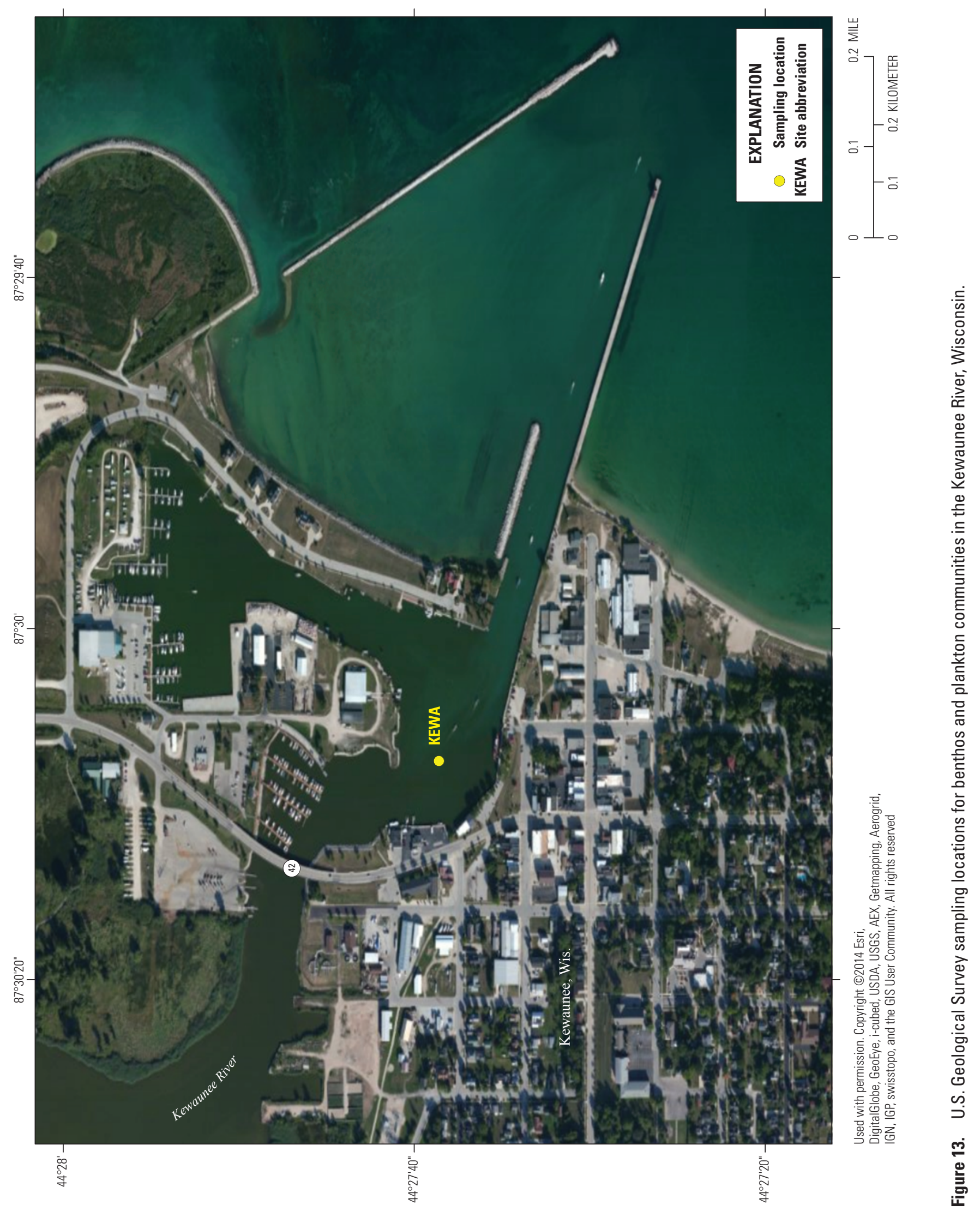




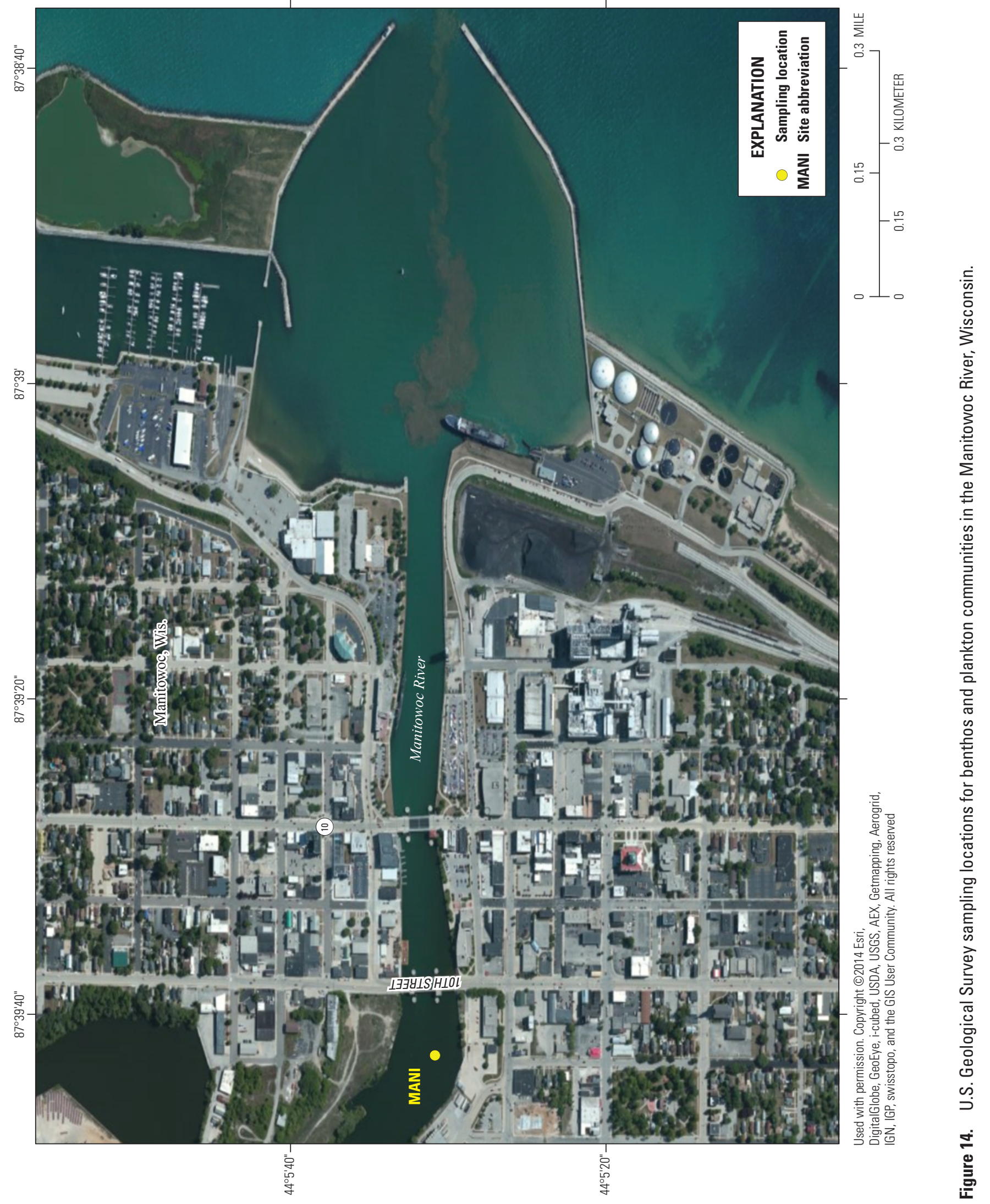




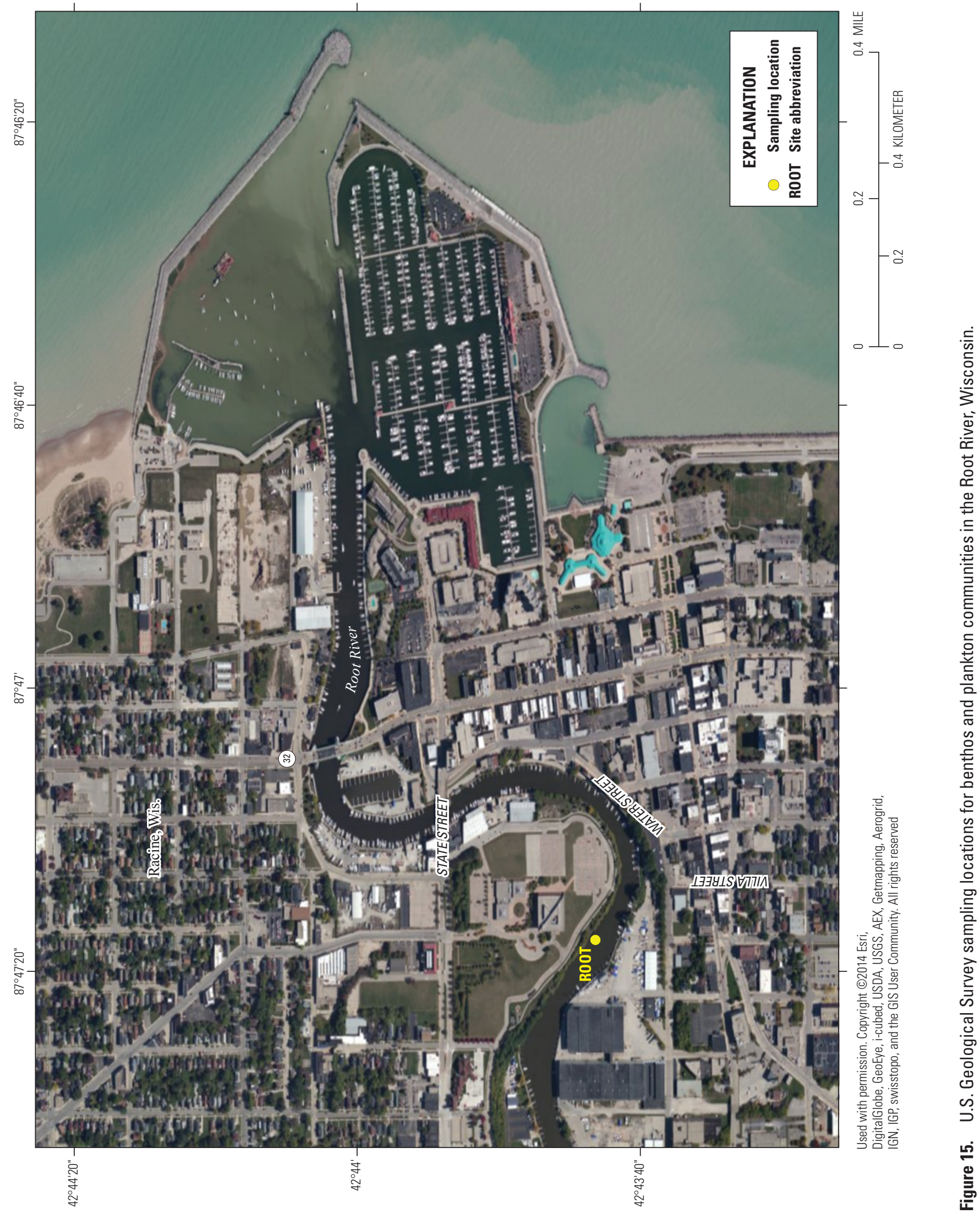




\section{Data Collection}

Benthos and plankton samples were collected from each of the 10 sites during 3 sampling events approximately 6 weeks apart in late May/early June, mid-July, and late August (hereafter, for simplicity, the 3 sampling events will be referred to as "seasons"). All sites were nonwadable, and therefore sampling was done by boat. All sampling at AOCs was done within AOC boundaries. During each sampling event, in situ water-quality measurements were taken for $\mathrm{pH}$, specific conductance, dissolved oxygen, and water temperature by use of a YSI sonde (appendix 1). Samples taken at each site consisted of two benthos and two plankton sampling techniques. Benthic grabs, plankton samples, and water-quality measurements were taken at the same location; Hester-Dendy (HD) artificial substrate samplers were deployed within $0.4 \mathrm{~km}$ of the Ponar samples. Collection methods were similar to those used in 2012 and described in Scudder Eikenberry and others (2014).

\section{Benthos Collection and Processing}

Benthos samples were collected at each site by two methods: dredge samples and HD artificial substrate samplers (U.S. Environmental Protection Agency, 1994; Weigel and Dimick, 2011). Three to four dredge samples were collected and composited into one sample per location by using a standard Ponar ${ }^{\circledR}$ dredge that collected a 229- by 229-millimeter ( $\mathrm{mm}$ ) sample from the upper layer of bottom sediment (fig. 16; U.S. Environmental Protection Agency, 2010a). A small amount of sediment ( $<50$ grams) from each composited dredge sample was split between two plastic bags for analyses of sandsilt-clay fractions and volatile-onignition of sediment (appendix 2). Large debris and empty shells in the remaining composite sample were examined for any attached invertebrates before being discarded, and fines were removed by sieving. The retained debris and organisms were stained with rose bengal dye and preserved with 10-percent buffered formalin (pH 7). Sediment samples were analyzed for sand-silt-clay fractions by the University of Wisconsin Soil and Plant Analysis Laboratory through the Wisconsin State Laboratory of Hygiene (WSLH), except for five samples analyzed by the USGS Kentucky Water Science
Center Sediment Laboratory because of low mass. Volatileon-ignition of sediment analyses were done at the USGS Wisconsin Water Science Center in Middleton, Wis. (Fishman and Friedman, 1989; Wentworth, 1922). Identification and enumeration of taxa in dredge samples was done by the Lake Superior Research Institute (LRSI) at the University of Wisconsin-Superior (U.S. Environmental Protection Agency, 2010b) (appendix 3).

The second type of benthos sample was collected by using HD samplers (Weigel and Dimick, 2011). At each location, two concrete blocks with two HD samplers each were deployed for 6 weeks during each season, and each block was independently anchored to an immobile structure such as a wing wall or pier piling within one-fourth of a mile of the dredge sampling location(s) (fig. 17). After about 6 weeks, to allow adequate time for colonization by invertebrates, the HD samplers and blocks were retrieved. Once retrieved, three of the four HD samplers were randomly chosen to represent the benthos community at the site, and the fourth HD sampler was used as a backup if one or more of the HD samplers was compromised. Samplers were then reassembled and redeployed for the next sampling event or were replaced if necessary. All organisms were scraped off and rinsed with tap water through a 500-micrometer $(\mu \mathrm{m})$ wash frame, composited into one sample per season for each site, stained with rose bengal dye, and preserved with 10-percent buffered formalin. Identification and counting of taxa in HD samples was done by the LRSI (U.S. Environmental Protection Agency, 2010b) (appendix 4).

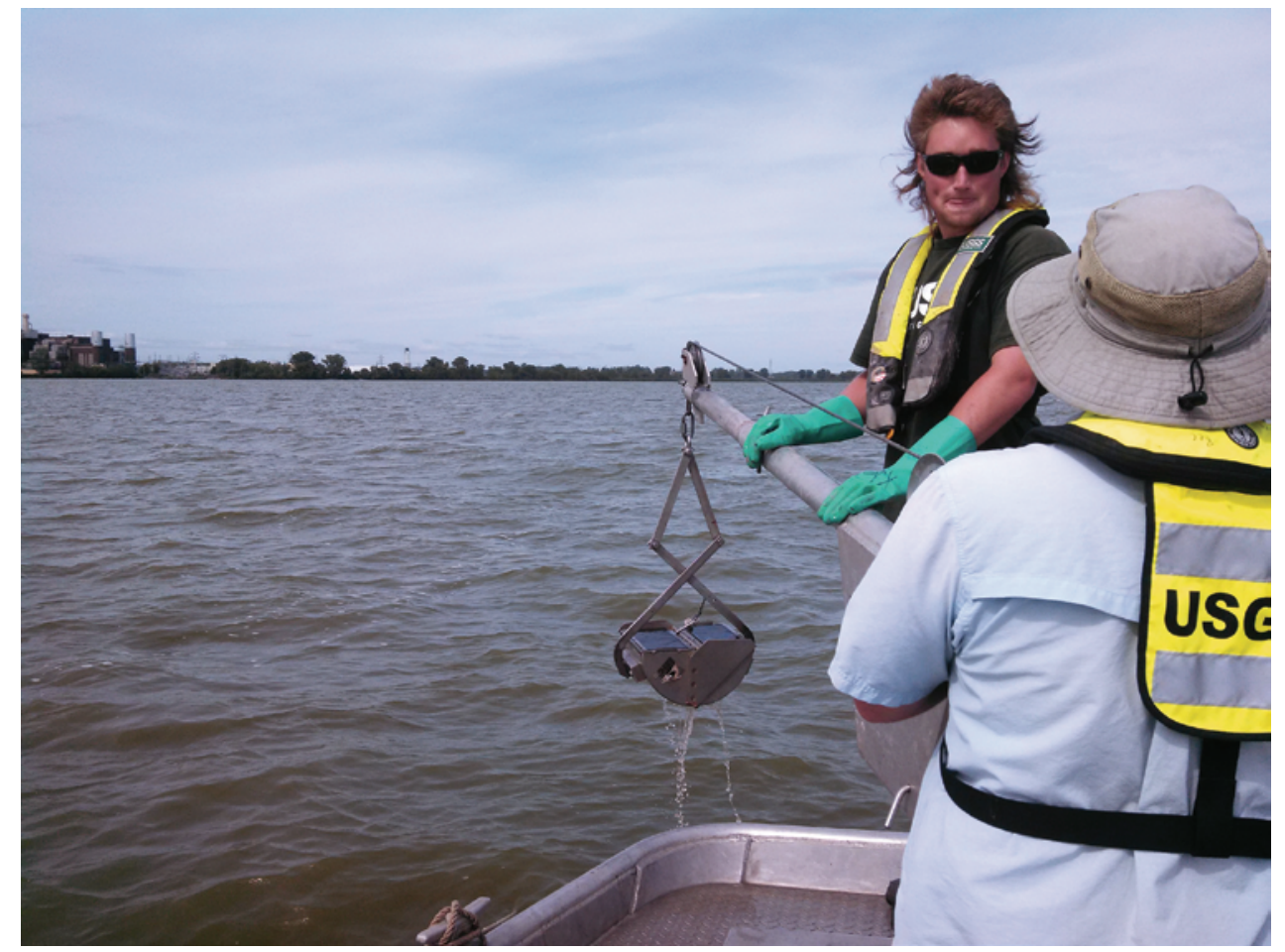

Figure 16. A Ponar dredge being retrieved with a sediment grab for a benthos community sample. 


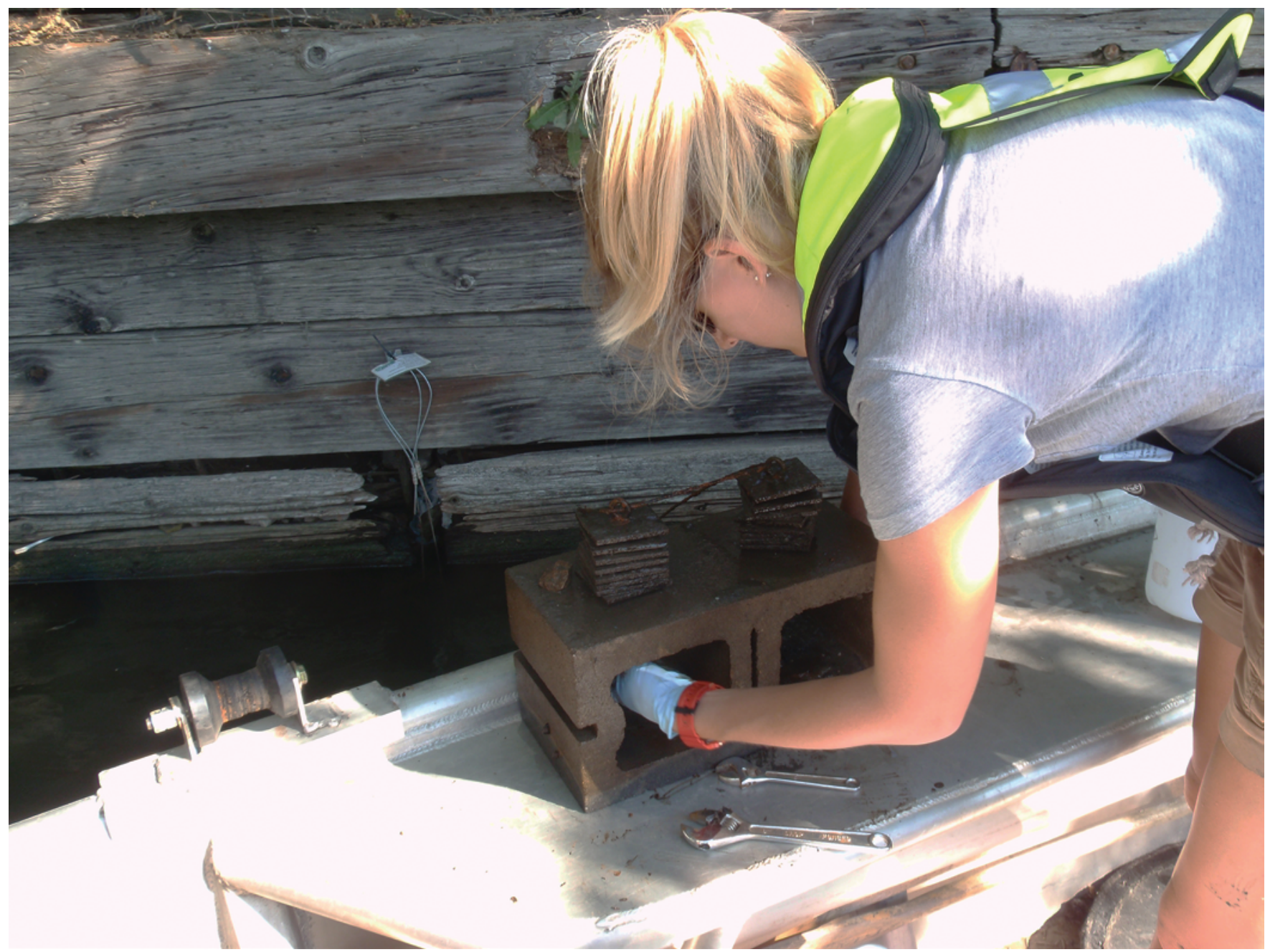

Figure 17. Hester-Dendy artificial substrate samplers retrieved for benthos community assessment.

\section{Plankton Collection and Processing}

Plankton samples for each site consisted of a net sample to capture larger zooplankton and a set of whole water samples to capture phytoplankton.

Zooplankton samples were collected by plankton net tows from a depth of 5 meters $(\mathrm{m})$ to the surface with a 63-micrometer mesh net, as described in the EPA's standard operating procedures for zooplankton sample collection and preservation (U.S. Environmental Protection Agency, 2010f). If the available depth was less than $5 \mathrm{~m}$, multiple tows were taken from just above the bottom to the surface until $5 \mathrm{~m}$ total depth was sampled. After each tow, the net was sprayed down with tap water to wash organisms into the sampling bucket, and samples were composited in a 500-milliliter $(\mathrm{mL})$ plastic bottle. Samples were preserved on shore with glutaraldehyde to a one-percent final solution (fig. 18). Preserved samples were sent to the WDNR for zooplankton identification and enumeration (U.S. Environmental Protection Agency, 2010e) (appendix 5).

For the phytoplankton samples, a Kemmerer vertical water sampler was used to collect a set of five whole water samples at 1-m depth intervals from $1 \mathrm{~m}$ below the surface to just above the bottom (U.S. Environmental Protection Agency, 2010d). The samples from each depth were composited in a bucket for subsampling and processing on shore (fig. 19). Several subsamples were taken from this composite sample. Approximately $500 \mathrm{~mL}$ of the composite was placed in a plastic bottle, preserved with glutaraldehyde to a 1-percent final solution, and sent to the WSLH for identification and enumeration of soft algae phytoplankton (blue-greens, cryptomonads, desmids, dinoflagellates, euglenoids, and greens) (Karner, 2005) (appendix 6). Approximately 1 liter of the sample was placed in a plastic bottle, preserved with glutaraldehyde to 


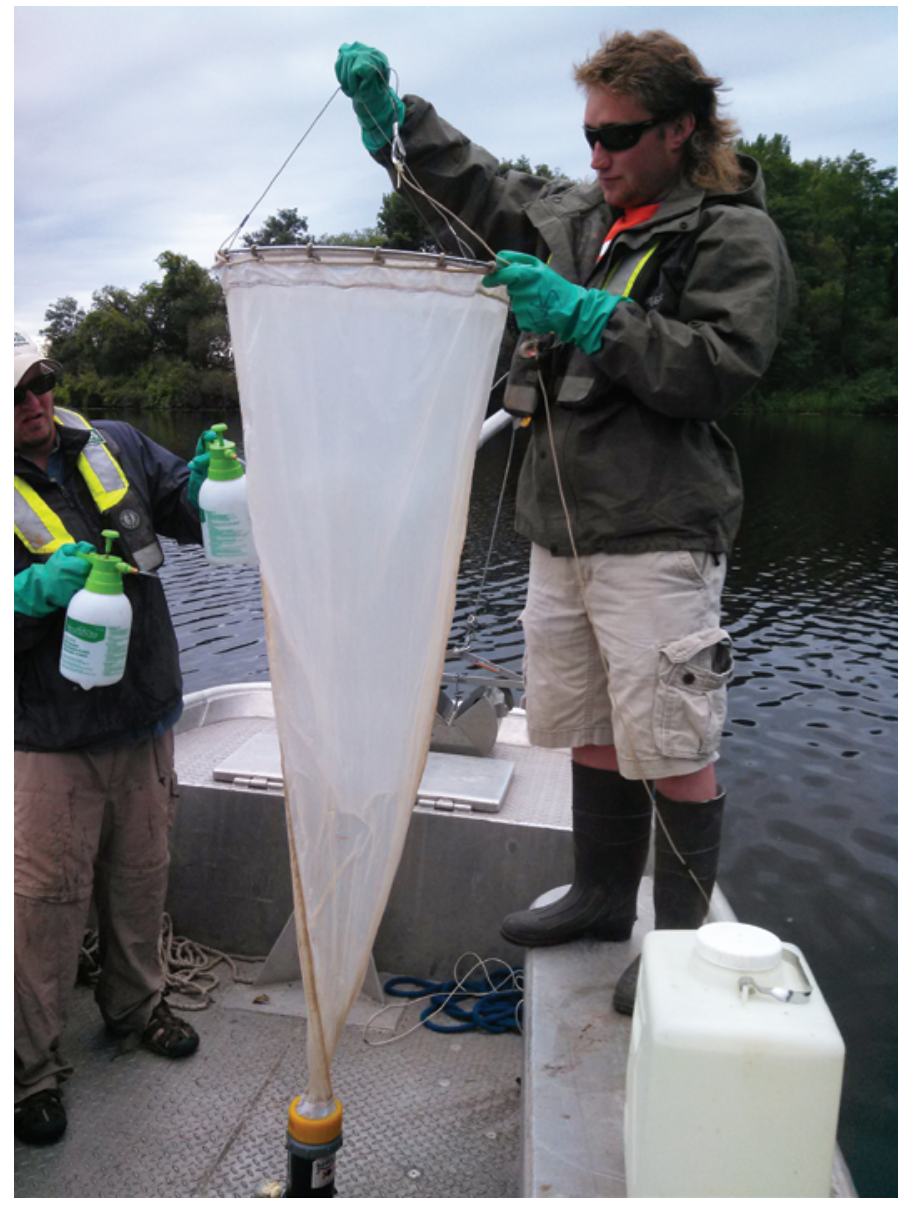

Figure 18. A plankton net being washed to collect a zooplankton community sample.

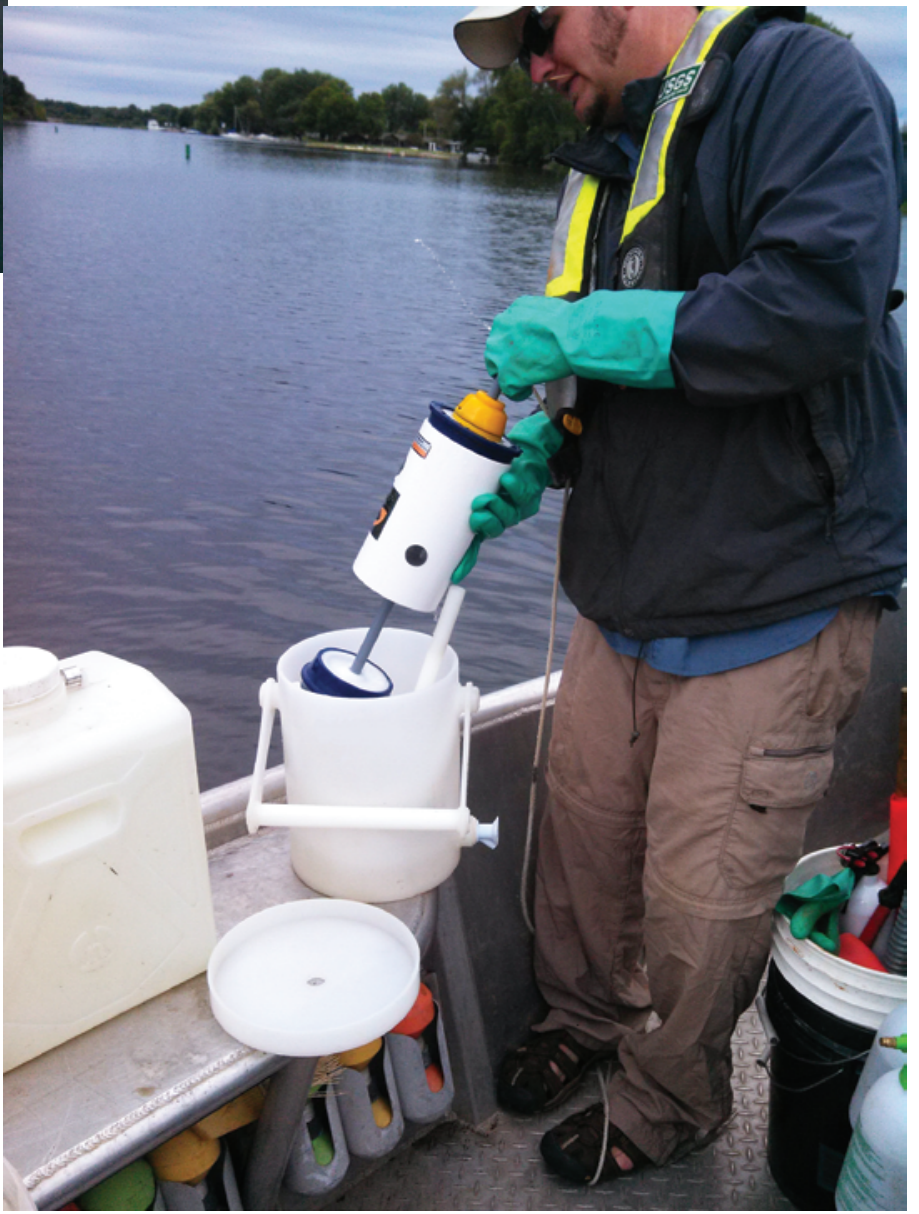

Figure 19. A Kemmerer vertical water sampler, after retrieval from depth, being emptied into a sample splitter to collect samples for phytoplankton community, chlorophyll $a$, and suspended solids. 
a 1-percent final solution, and sent to the WDNR for diatom phytoplankton identification and enumeration (U.S. Environmental Protection Agency, 2010c) (appendix 7). A minimum of $50 \mathrm{~mL}$ was filtered in the field for chlorophyll $a$ with a Millipore type SM membrane filter (47-mm diameter $5.0-\mu \mathrm{m}$ pore size), which was then placed in an analysis vial, wrapped in aluminum foil, and preserved with dry ice until delivery to the WSLH for analysis (Kennedy-Parker, 2011) (appendix 8). A minimum of $50 \mathrm{~mL}$ was filtered for total suspended solids and volatile suspended solids through a Whatman glass fiber filter (1.5- $\mu \mathrm{m}$ pore size), which was then wrapped in aluminum foil, placed in a petri dish, and preserved with dry ice until delivery to the WSLH (American Public Health Association, American Water Works Association, and Water Environment Federation, 2006) (appendix 8).

\section{Quality Assurance and Quality Control}

Quality assurance and quality control (QA-QC) samples were collected during each sampling period to evaluate field variability of taxonomic results. Primary and replicate samples were collected at two sites, the Sheboygan River AOC and its non-AOC comparison site, the Manitowoc River. Primary and replicate samples were compared by using the SIMPER routine in PRIMER software to compare similarity matrixes of the taxonomic data (Clarke and Gorley, 2006). Similarities greater than 60 percent were considered acceptable for QAQC purposes (Kelly, 2001). Primary and replicate samples at both sites had similarities greater than 60 percent except for fall (late August) diatom samples. Because of the fall diatom samples, similarities for fall combined algae samples were also low (table 2). Fall diatom densities in Sheboygan River primary and replicate samples were dominated ( $>75$ percent) by one colony-forming centric taxon, and overall there were fewer taxa and greater densities in the replicate samples. Fall diatom densities in Manitowoc River primary and replicate samples were dominated by other colony-forming centric taxa. It is often difficult to precisely characterize biological communities that have patchy distributions and low abundances, especially algal blooms that result from eutrophication. By use of relative abundances for combined algae samples in comparisons among AOCs, the effect of the fall diatom taxa differences on the overall phytoplankton comparisons was lessened. Overall, however, QA-QC results indicated minimal variability among field replicates within each season for most taxonomic groups.

Table 2. Quality assurance and quality control (OA-OC) results for replicate samples of benthos and plankton collected in 2014 at the Sheboygan and Manitowoc Rivers, Wisconsin, showing similarity for relative abundance of taxa collected within each season.

[Similarities greater than 60 percent, indicating QA-QC results within acceptable limits, are in gray. Refer to table 1 for the complete site and subsite names]

\begin{tabular}{|c|c|c|c|c|c|}
\hline Site & Taxonomic group & $\begin{array}{l}\text { Spring similarity } \\
\text { (percent) }\end{array}$ & $\begin{array}{c}\text { Summer similarity } \\
\text { (percent) }\end{array}$ & $\begin{array}{c}\text { Fall similarity } \\
\text { (percent) }\end{array}$ & $\begin{array}{c}\text { Average similarity } \\
\text { (percent) }\end{array}$ \\
\hline \multirow[t]{5}{*}{ Sheboygan River } & Benthos (combined) & 77.5 & 69.6 & 64.1 & 70.4 \\
\hline & Zooplankton with nauplii & 85.6 & 78.2 & 83.6 & 82.5 \\
\hline & Diatoms & 71.5 & 66.6 & 34.8 & 57.6 \\
\hline & Soft algae & 82.5 & 84.4 & 84.9 & 83.9 \\
\hline & Algae (combined) & 73.4 & 69.1 & 52.2 & 64.9 \\
\hline \multirow[t]{5}{*}{ Manitowoc River } & Benthos (combined) & 74.2 & 67.5 & 66.4 & 69.4 \\
\hline & Zooplankton with nauplii & 79.4 & 72.3 & 84.4 & 78.7 \\
\hline & Diatoms & 60.2 & 62.3 & 34.1 & 52.2 \\
\hline & Soft algae & 78.0 & 98.2 & 89.5 & 88.6 \\
\hline & Algae (combined) & 63.3 & 66.3 & 46.2 & 58.6 \\
\hline
\end{tabular}




\section{Summary}

This report describes study areas and field sampling methods and provides data collected in 2014 by the U.S. Geological Survey, in cooperation with the Wisconsin Department of Natural Resources and the U.S. Environmental Protection Agency, for characterization of benthos (benthic invertebrates) and plankton (zooplankton and phytoplankton) communities at 4 Area of Concern (AOC) and 6 non-AOC rivers and harbors along the western Lake Michigan shoreline. The 4 AOCs are the Lower Menominee River, Lower Green Bay and Fox River, Sheboygan River, and Milwaukee Estuary (Milwaukee River, Menomonee River, and Milwaukee Harbor); the 6 non-AOCs sampled for comparison with the AOCs are the Escanaba River, Oconto River, Ahnapee River, Kewaunee River, Manitowoc River, and Root River. In addition to the data on the abundance and distribution of benthos and plankton taxa at these sites, ancillary data are included for sediment characterization (percentages of sand, silt, and clay), algal biomass (chlorophyll $a$, total and volatile suspended solids), and water quality (water temperature, $\mathrm{pH}$, specific conductance, and dissolved oxygen). The data collection described in this report, as well as data collection in the same study areas and by the same field sampling methods in 2012, are part of a study designed to assess the status of the benthos and plankton communities in the AOCs in comparison to those at the non-AOCs for evaluation of the related Beneficial Use Impairments at the AOCs.

\section{References Cited}

American Public Health Association, American Water Works Association, and Water Environment Federation, 2005, Fixed and volatile solids ignited at $550^{\circ} \mathrm{C}$, part 2540 E. of Eaton, A.D., Rice, E.W., and Baird, R.B., eds., Standard methods for the examination of water and wastewater (21st ed.): Washington, D.C., American Public Health Association, p. 2-55-2-61.

Clarke, K.R., and Gorley, R.N., 2006, PRIMER v6: User's manual/tutorial: Plymouth, United Kingdom, Primer-E Ltd., $190 \mathrm{p}$.

Fishman, M.J., and Friedman, L.C., 1989, Solids, volatile-onignition, total-in-bottom-material, gravimetric, in Fishman, M.J., and Friedman, L.C., eds., Methods for determination of inorganic substances in water and fluvial sediments (3d ed.): U.S. Geological Survey Techniques of WaterResources Investigations, book 5, chap. A1, p. 451.

International Joint Commission, United States and Canada, 1987, Protocol amending the 1978 agreement between the United States of America and Canada on Great Lakes water quality as amended on October 16, 1983: International Joint Commission, United States and Canada, 75 p.
Karner, Dawn, 2005, ESS BIO METHOD 2035: Phytoplankton Identification and Enumeration: Madison, Wis., Wiscon$\sin$ State Laboratory of Hygiene, $11 \mathrm{p}$.

Kelly, M.G., 2001, Use of similarity measures for quality control of benthic diatom samples: Water Research, v. 35, no. 11, p. 2784-2788.

Kennedy-Parker, D., 2011, ESS INO METHOD 151.1 (EPA 445.0, rev. 1.2, Sept. 1997 and Welschmeyer, 1994): Chlorophyll $a$, Fluorescence: Madison, Wis., Wisconsin State Laboratory of Hygiene, $15 \mathrm{p}$.

Michigan Department of Community Health, 2015, Michigan Department of Community Health's eat safe fish guideUpper Peninsula, 2015: Michigan Department of Community Health regional Eat Safe Fish Guide, 79 p., accessed March 9, 2016, at https://www.michigan.gov/documents/ $\mathrm{mdch} / \mathrm{MDCH}$ EAT_SAFE_FISH_GUIDE_-_UPPER_PENINSULA_WEB_455361_7.pdf

Rost, R.A., Brand, J.C., Bruch, R.M., Crehore, D.H., Dodson, S.I., Fassbender, R.L., Herman, L.J., Rasman, T.F., and Stranz, A.M., 1989, Water quality and restoration of the Lower Oconto River, Oconto County, Wisconsin: Madison, Wis., Wisconsin Department of Natural Resources, 40 p.

Scudder Eikenberry, B.C., Bell, A.H., Burns, D.J., and Templar, H.A., 2014, Benthos and plankton community data for selected rivers and harbors along Wisconsin's Lake Michigan shoreline, 2012: U.S. Geological Survey Data Series 824,30 p. plus 8 appendixes, accessed September 19, 2014, at http://dx.doi.org/10.3133/ds824.

U.S. Environmental Protection Agency, 1994, Assessment of benthic invertebrate community structure, chap. 7 of ARCS assessment guidance document: Chicago, Great Lakes National Program Office, U.S. Environmental Protection Agency, report 905-B94-002, p. 131-175.

U.S. Environmental Protection Agency, 2010a, Standard operating procedure for benthic invertebrate field sampling (LG406), in Sampling and analytical procedures for GLNPO's Open Lake Water Quality Survey of the Great Lakes: Chicago, Great Lakes National Program Office, U.S. Environmental Protection Agency, report EPA 905-R-05001, 9 p., accessed March 9, 2016, at https://www3.epa.gov/ greatlakes/monitoring/sop/.

U.S. Environmental Protection Agency, 2010b, Standard operating procedure for benthic invertebrate laboratory analysis (LG407), in Sampling and analytical procedures for GLNPO's Open Lake Water Quality Survey of the Great Lakes: Chicago, Great Lakes National Program Office, U.S. Environmental Protection Agency, report EPA 905-R-001, 12 p., accessed March 9, 2016, at https://www3.epa.gov/ greatlakes/monitoring/sop/. 
U.S. Environmental Protection Agency, 2010c, Standard operating procedure for phytoplankton analysis (LG401), in Sampling and analytical procedures for GLNPO's Open Lake Water Quality Survey of the Great Lakes: Chicago, Great Lakes National Program Office, U.S. Environmental Protection Agency, report EPA 905-R-001, 44 p., accessed March 9, 2016, at https://www3.epa.gov/greatlakes/ monitoring/sop/.

U.S. Environmental Protection Agency, 2010d, Standard operating procedure for phytoplankton sample collection and preservation field procedures (LG400), in Sampling and analytical procedures for GLNPO's Open Lake Water Quality Survey of the Great Lakes: Chicago, Great Lakes National Program Office, U.S. Environmental Protection Agency, report EPA 905-R-001, 7 p., accessed March 9, 2016, at https://www3.epa.gov/greatlakes/monitoring/sop/.

U.S. Environmental Protection Agency, 2010e, Standard operating procedure for zooplankton analysis (LG403), in Sampling and analytical procedures for GLNPO's Open Lake Water Quality Survey of the Great Lakes: Chicago, Great Lakes National Program Office, U.S. Environmental Protection Agency, report EPA 905-R-001, 20 p., accessed March 9, 2016, at https://www3.epa.gov/greatlakes/ monitoring/sop/.

U.S. Environmental Protection Agency, 2010f, Standard operating procedure for zooplankton sample collection and preservation and Secchi depth measurement field procedures (LG402), in Sampling and analytical Procedures for GLNPO's Open Lake Water Quality Survey of the Great Lakes: Chicago, Great Lakes National Program Office, U.S. Environmental Protection Agency, report EPA 905-R001, 9 p., accessed March 9, 2016, at https://www3.epa.gov/ greatlakes/monitoring/sop/.

U.S. Environmental Protection Agency, 2013a, Great Lakes Areas of Concern-Lower Green Bay and Fox River: U.S. Environmental Protection Agency Web page, accessed March 9, 2016, at http://www.epa.gov/green-bay-fox-riveraoc.

U.S. Environmental Protection Agency, 2013b, Great Lakes Areas of Concern-Menominee River: U.S. Environmental Protection Agency Web page, accessed March 9, 2016, at http://www.epa.gov/menominee-river-aoc.

U.S. Environmental Protection Agency, 2013c, Great Lakes Areas of Concern - Milwaukee Estuary: U.S. Environmental Protection Agency Web page, accessed March 9, 2016, at http://www.epa.gov/milwaukee-estuary-aoc.

U.S. Environmental Protection Agency, 2015, EPA Superfund Program: WPSC Manitowoc MGP, Manitowoc, WI: U.S. Environmental Protection Agency Web page, accessed March 9, 2016, at http://cumulis.epa.gov/supercpad/cursites/ csitinfo.cfm?id=0509949.
Weigel, B.M., and Dimick, J.J., 2011, Development, validation, and application of a macroinvertebrate-based index of biotic integrity for nonwadeable rivers of Wisconsin: Journal of the North American Benthological Society, v. 30, no. 3, p. 665-679.

Wentworth, C.K., 1922, A scale of grade and class terms for clastic sediments: Journal of Geology, v. 30, no. 5, p. 377392.

Wisconsin Department of Natural Resources, 1994, Milwaukee Estuary Remedial Action Plan-Progress through January 1994: Madison, Wis., Wisconsin Department of Natural Resources, variously paged, accessed March 8, 2016, at http://nnr.wi.gov/topic/greatlakes/documents/ MilwaukeeEstuaryRAP1994.pdf.

Wisconsin Department of Natural Resources, 1995, Sheboygan River RAP [Remedial Action Plan]: Madison, Wis., Wisconsin Department of Natural Resources, 271 p.

Wisconsin Department of Natural Resources, 2012, Remedial Action Plan Update for the Sheboygan River Area of Concern: Madison, Wis., Wisconsin Department of Natural Resources, $72 \mathrm{p}$.

Wisconsin Department of Natural Resources, 2013, Sheboygan River Area of Concern Beneficial Use Impairment restoration report (Summer 2013 ed.): Madison, Wis., Wisconsin Department of Natural Resources, 4 p.

Wisconsin Department of Natural Resources, 2014a, Remedial Action Plan Update for the Lower Green Bay and Fox River Area of Concern: Madison, Wis., Wisconsin Department of Natural Resources, 47 p.

Wisconsin Department of Natural Resources, 2014b, Remedial Action Plan Update for the Milwaukee Estuary Area of Concern: Madison, Wis., Wisconsin Department of Natural Resources, $63 \mathrm{p}$.

Wisconsin Department of Natural Resources, 2014c, Remedial Action Plan Update for the Sheboygan River Area of Concern: Madison, Wis., Wisconsin Department of Natural Resources, $47 \mathrm{p}$.

Wisconsin Department of Natural Resources, 2015a, 2014 Remedial Action Plan Update for the Lower Menominee River Area of Concern: Madison, Wis., Wisconsin Department of Natural Resources, 69 p.

Wisconsin Department of Natural Resources, 2015b, Choose wisely - 2015-A health guide for eating fish in Wisconsin: Madison, Wisconsin, Wisconsin Department of Natural Resources, $44 \mathrm{p}$. 
Wisconsin Department of Natural Resources and Lakeshore Basin Partnership Team, 2001a, Twin Door Kewaunee Basin watershed-Narratives and tables, appendix v of Wisconsin Department of Natural Resources and Lakeshore Basin Partnership Team, The state of the Lakeshore Basin: Madison, Wis., Wisconsin Department of Natural Resources, $59 \mathrm{p}$.

Wisconsin Department of Natural Resources and Lakeshore Basin Partnership Team, 2001b, The State of the Lakeshore Basin: Madison, Wis., Wisconsin Department of Natural Resources, $45 \mathrm{p}$.

Wisconsin Department of Natural Resources and Michigan Department of Environmental Quality, 2011, Stage 2 Remedial Action Plan for the Lower Menominee River Area of Concern: Madison, Wis., Wisconsin Department of Natural Resources, 81 p., accessed March 9, 2016, at http://dnr.wi.gov/topic/greatlakes/documents/Stage2RAPLowerMenomineeRiver.pdf. 


\section{Appendixes 1-8}

The data files listed below are included as part of U.S. Geological Survey (USGS) Data Series 1000 and are available for download at http://dx.doi.org/10.3133/ds1000. The data were collected in 2014 as part of the USGS benthic invertebrate and plankton community data for selected rivers and harbors along Wisconsin's Lake Michigan shoreline. See the report text for details about the study and for information on collection and processing of all data. The data files are available as Microsoft Excel (.xlsx) and comma-separated value (.csv) files formatted to properly display the data. Federal Geographic Data Committee-compliant metadata accompany these tabular datasets. 
Appendix 1. Water-Quality Measurements Made In Situ with a Ysi Sonde, Collected as Part of the U.S. Geological Survey Benthos and Plankton Community Data for Selected Rivers and Harbors Along Wisconsin's Lake Michigan Shoreline, 2014

[Excel and .csv files available at http://dx.doi.org/10.3133/ds1000]

Appendix 2. Sediment Size Fractions and Volatile-On-Ignition Data for Composite Benthic Grabs Made With a Ponar Dredge, Collected as Part of the U.S. Geological Survey Benthos and Plankton Community Data for Selected Rivers and Harbors Along Wisconsin's Lake Michigan Shoreline, 2014

[Excel and .csv files available at http://dx.doi.org/10.3133/ds1000]

Appendix 3. Invertebrate Taxonomic Data for Composited Benthic Grabs Made With a Ponar Dredge, Collected as Part of the U.S. Geological Survey Benthos and Plankton Community Data for Selected Rivers and Harbors Along Wisconsin's Lake Michigan Shoreline, 2014

[Excel and .csv files available at http://dx.doi.org/10.3133/ds1000]

Appendix 4. Invertebrate Taxonomic Data for Composited Hester-Dendy Artificial Substrate Samplers, Collected as Part of the U.S. Geological Survey Benthos and Plankton Community Data for Selected Rivers and Harbors Along Wisconsin's Lake Michigan Shoreline, 2014 
Appendix 5. Zooplankton Taxonomic Data for Composited Plankton Tows, Collected as Part of the U.S. Geological Survey Benthos and Plankton Community Data for Selected Rivers and Harbors Along Wisconsin's Lake Michigan Shoreline, 2014

[Excel and .csv files available at http://dx.doi.org/10.3133/ds1000]

Appendix 6. Soft Algae Taxonomic Data for Composited Water Samples from a Kemmerer Vertical Water Sampler, Collected as Part of the U.S. Geological Survey Benthos and Plankton Community Data for Selected Rivers and Harbors Along Wisconsin's Lake Michigan Shoreline, 2014

[Excel and .csv files available at http://dx.doi.org/10.3133/ds1000]

Appendix 7. Diatom Taxonomic Data for Composited Water Samples from a Kemmerer Vertical Water Sampler, Collected as Part of the U.S. Geological Survey Benthos and Plankton Community Data for Selected Rivers and Harbors Along Wisconsin's Lake Michigan Shoreline, 2014

[Excel and .csv files available at http://dx.doi.org/10.3133/ds1000]

Appendix 8. Chlorophyll a, Total and Volatile Suspended Solids for Composited Water Samples from a Kemmerer Vertical Water Sampler, Collected as Part of the U.S. Geological Survey Benthos and Plankton Community Data for Selected Rivers and Harbors Along Wisconsin's Lake Michigan Shoreline, 2014 

For more information concerning this report, contact: Director, Wisconsin Water Science Center

U.S. Geological Survey

505 Science Drive, Suite A

Madison, WI 53711

jfwalker@usgs.gov

or visit our Web site at:

http://wi.water.usgs.gov

Publishing support by:

The Pembroke and Madison Publishing Service Centers 


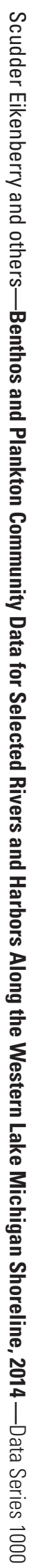

ISSN 2327-638X (online)

http://dx.doi.org/10.3133/ds1000 